\title{
Ability of Cistus L. shrubs to promote soil rehabilitation in extensive oak woodlands of Mediterranean areas
}

\author{
Maria Paula Simões • Manuel Madeira • \\ Luiz Gazarini
}

Received: 16 September 2008 / Accepted: 10 February 2009/Published online: 11 March 2009

(C) Springer Science + Business Media B.V. 2009

\begin{abstract}
To assess the ecological function of Cistus salviifolius (CS) and C. ladanifer (CL) shrubs in evergreen oak woodlands, a study was conducted over a 4-year period in southern Portugal. Annual potential return of bio-elements to the soil through litterfall and throughfall, and necromass on soil surface under shrub canopies were assessed along with the dynamics of leaf litter decomposition. Soil bulk density and soil-water retention at different soil matric potential were measured at $0-5$ and $5-10 \mathrm{~cm}$ depth, and soil chemical properties were determined at $0-5,5-10,10-20$ and $20-30 \mathrm{~cm}$ depth beneath canopies and at barren spaces. Litterfall was higher for CL (4.4-4.6 Mg DM ha ${ }^{-1}$ year $^{-1}$ ) than for CS (3.3-3.8 Mg DM ha ${ }^{-1}$ year $\left.^{-1}\right)$. Annual amount of $\mathrm{N}$ returned to the soil through litterfall of CS $(22.9 \mathrm{~kg} \mathrm{~N}$ $\mathrm{ha}^{-1}$ year $\left.^{-1}\right)$ was higher than by that of CL $(17.2 \mathrm{~kg} \mathrm{~N}$ $\mathrm{ha}^{-1}$ year $\left.^{-1}\right)$, whereas the return of P in CL (4.1 kg P
\end{abstract}

Responsible Editor: Alfonso Escudero.

M. P. Simões $(\bowtie) \cdot$ L. Gazarini

Instituto de Ciências Agrárias Mediterrânicas/

Departamento de Biologia, Universidade de Évora,

Apartado 94,

7002-554 Évora, Portugal

e-mail: mps@uevora.pt

M. Madeira

Instituto Superior de Agronomia,

Universidade Técnica de Lisboa,

Tapada da Ajuda,

1349-017 Lisboa, Portugal $\mathrm{ha}^{-1}$ year $\left.^{-1}\right)$ was higher than in CS $\left(2.1 \mathrm{~kg} \mathrm{P} \mathrm{ha}^{-1}\right.$ year $\left.^{-1}\right)$. Leaf decomposition was faster for CS $(k=$ $-0.87)$ than for CL $(k=-0.44)$. $\mathrm{N}$ release was also faster for CS than for CL, while that of $\mathrm{P}$ was much faster for $\mathrm{CL}$ than for CS. Throughfall proportions were $61 \%$ of bulk rainfall for CS and $79 \%$ for CL. Annual return of $\mathrm{Cl}^{-}, \mathrm{K}^{+}, \mathrm{Ca}^{2+}$ and $\mathrm{Mg}^{2+}$ by throughfall was more pronounced for CL than for CS. Shrubs improved soil quality, especially in the $0-5 \mathrm{~cm}$ top soil layer, by enhancement of organic matter and nutrient content beneath shrub canopies. Therefore, shrubs may promote the invasion of more demanding species, since local areas of high fertility are likely to be favoured sites for vegetation regeneration.

Keywords Oak woodlands · Mediterranean shrubs · Litterfall · Decomposition · Throughfall · Potential return of bio-elements $\cdot$ Soil rehabilitation

\section{Introduction}

The landscape of southern Portugal is mostly dominated by a multi-purpose agroforestry system, characterised by scattered oak trees, which create a mosaic of open pastureland and oak/understory plant communities. Quercus suber and Q. rotundifolia are the dominant tree species of these man-made savannah-type ecosystems that occupy an estimated area of $1.1 \times 10^{6}$ ha (DGF 2007) in Portugal. These ecosystems play an important role on the rural economy (Joffre et al. 1999) 
and have been considered an example of integration of traditional and sustainable land-use and biodiversity conservation (Blondel and Aronson 1999).

After the abandonment of cereal crops and livestock rearing, in the seventies of the last century, cultivated land reverted to seminatural vegetation, and shrub clearing and rotational ploughing became common to control shrub invasion, to promote pasture production and prevent fire (Pulido et al. 2001; Plieninger et al. 2003, 2004). The disappearance of the protective cover of shrub vegetation intensified the erosive processes and the structural breakdown of soil, because of the progressive decrease in soil organic matter (SOM) (Andreu et al. 1998). Nowadays, these systems are seriously threatened, being soil erosion, absence of tree natural regeneration, die-back and loss of biodiversity some of the most outstanding threats (Plieninger et al. 2003, 2004; Eichhorn et al. 2006). The impacts of global change, like the forecasted increase of air temperature and drought in Mediterranean areas (Miranda et al. 2002), can potentiate the threats and hence the degradation of oak woodlands and their sustainability can be questioned, at least under the current management practices.

Recently it has been argued that shrub encroachment may have some advantages (Pulido and Díaz 2005) and potential strategies to enhance oak regeneration include promotion of spatial heterogeneity and restoration of shrub layer (Plieninger et al. 2004; Ramos Solano et al. 2006; Moreno and Obrador 2007). Survival of seedlings and hence a tendency for regeneration to occur on safe microsites protected from browsing and radiation underneath shrub cover has already been documented (Plieninger et al. 2003, 2004). Moreover, shrubs are considered to play a major role on soil erosion control (Andreu et al. 1998), especially after fire events and constitute habitat for a great deal of game. Thus, spatially and temporally limited set-aside of grazing and cultivation can result in a landscape mosaic of intermediately disturbed patches, so that a variety of successional stages are developed (Fulbright 1996; Plieninger et al. 2003).

Shrubs of the genus Cistus (Cistaceae) are among the most important elements of shrublands and encroached oak woodlands which currently dominate large areas in central and southern Portugal (Simões et al. 2008). Cistus salviifolius L. and C. ladanifer L. are undoubtedly the most representative species in oak woodland areas degraded by previous cereal crops and livestock overgrazing (Martín Bolaños and Guinea López 1949). Several studies developed at tree level in Mediterranean oak woodlands, including Portugal (Nunes 2004), have shown that trees provide carbon sequestration and enhance SOM and nutrient pools beneath the canopies, preventing thus soil erosion and land degradation. However, few studies have focused so far the potential role of encroachment on the recovery of soil physical and chemical quality, and on tree natural regeneration and system sustainability. Although some attention has been paid to the $\mathrm{C}$ and $\mathrm{N}$ stocks in the aboveground shrub compartment (Moro et al. 1996; Castells and Peñuelas 2003; Simões et al. 2008), there is no information whether encroachment affect the pattern and scale of soil $\mathrm{C}$ and $\mathrm{N}$ spatial heterogeneity. Since nutrient cycling in oak woodlands is spatially complex and may be strongly influenced by rangeland management practices (Dahlgren et al. 1997), knowledge on the role of shrubs on nutrient cycling and on the restoration of soil quality will provide information to lay down general guidelines for proper management in these systems, in order to promote soil recovery and system regeneration and sustainability to face degradation threats.

In this context, a study was carried out in an oak woodland with low tree density, previously used for extensive grazing, to assess the interactions between shrub understory and soil, in order to find out possible short and long-term effects of shrubs on soil resources of both shrublands and encroached oak woodlands. The aims of the study were (i) to determine and compare the potential return of bio-elements to the soil through litterfall and throughfall of the main shrubs, C. salviifolius L. and C. ladanifer L., (ii) to evaluate the accumulation and turnover of SOM under shrub influence, and (iii) to assess shrub effects on soil physical properties and nutrient pools. Data will be discussed taking also into account information gathered for scattered trees in oak woodlands.

\section{Materials and methods}

Study area

The study was carried out in southern Portugal, in a site close to Évora, (38 $32^{\prime} \mathrm{N} ; 8^{\circ} 01^{\prime} \mathrm{W} ; 240 \mathrm{~m}$ a.s.l.), during 2003-2007. The area has the typical winterwet, summer dry pattern of the Mediterranean-type 
climate. Mean annual rainfall is $665 \mathrm{~mm} \mathrm{year}^{-1}$, mean annual temperature is $15.4^{\circ} \mathrm{C}$, that of the warmest month (August) is $23.1^{\circ} \mathrm{C}$ and the coldest (January) is $8.6^{\circ} \mathrm{C}(1951-1980$, Reis and Gonçalves 1987). The annual average of relative humidity is about $70 \%$. In terms of the bioclimate typology (Rivas-Martínez et al. 2004) it is located in the Mesomediterranean, lower dry to subhumid belt of the Mediterranean pluviseasonal-oceanic bioclimate, and biogeographically stands as the LusitanExtremadurean Province (Marianic-Monchiquensean Sector) of the Mediterranean region.

The landscape is gently undulating with slopes varying from 3 to $8 \%$, and the geological substratum consists of granites and gneisses (Carvalhosa et al. 1969). The soils are developed from granites and correspond to dystric Leptosols and dystric Cambisols (WRB 2006), and their content of coarse fragments reaches $30-40 \%$. They predominantly show a sandy texture, loam sandy to sandy loam, low contents of organic $\mathrm{C}\left(6-10 \mathrm{~g} \mathrm{~kg}^{-1}\right)$; $\mathrm{pH}\left(\mathrm{H}_{2} \mathrm{O}\right)$ values range from 4.9 to 5.3 and contents of extractable $\mathrm{Ca}, \mathrm{Mg}, \mathrm{K}$ and $\mathrm{Na}$ range, respectively, $1.2-1.9,0.5-0.8,0.05-0.15$ and $0.14-0.20 \mathrm{cmol}_{\mathrm{c}} \mathrm{kg}^{-1}$. Extractable $\mathrm{P}$ is very low, ranging from 1 to $9 \mathrm{mg} \mathrm{kg}^{-1}$ (Nunes 2004).

The vegetation of the study area is an open oak woodland of Quercus suber L. and Q. rotundifolia Lam., with 10-45 trees $\mathrm{ha}^{-1}$, included in the series Pyro bourgaeanae-Quercetum rotundifoliae S. Nevertheless, the dominant plant formation is a scrubland belonging to Hyacinthoido-Quercetum coccifera, which represents the first substitution stage of the aforementioned series. The scrubland patches are dominated by Cistus salviifolius L. and C. ladanifer L., which account for $>70 \%$ of the community cover. The subordinate species in the community are mostly evergreen sclerophylls and drought semi-deciduous shrubs, including C. crispus L., Quercus coccifera L., Myrtus communis L., Arbutus unedo L., Rosmarinus officinalis L. and Lavandula stoechas L., sparsely distributed. The study area was used for goat grazing until 1991. By that time, it was fenced, to prevent grazing and protect vegetation.

\section{Study species}

C. salviifolius and C. ladanifer (hereafter named CS and $\mathrm{CL}$, respectively) are drought semi-deciduous shrubs, occurring in typical Mediterranean dry hab- itats, forming both extensive pure stands and sparse populations. CS occurs over almost the whole Mediterranean basin and is widespread throughout the Iberian Peninsula, while CL is restricted to the south of France, the western half of the Iberian Peninsula and northern Africa (Morocco and Algeria) (Castroviejo et al. 1993). They inhabit nutrient-poor or degraded dry soils, either siliceous (granite or schist) or calcareous (Castroviejo et al. 1993), although CS prefers sandy soils (Martín Bolaños and Guinea López 1949). Both species multiply naturally by seed and possess an opportunistic strategy of seed germination, associated with the early post-disturbance successional stages (Pérez-García 1997). Although CL is more thermophilic than CS, usually occupying the most degraded habitats, they both are abundant in warm open areas subjected to repeated and intense disturbance (e.g. fire, wood cutting or agriculture abandonment) and subsequent erosion of the upper layer of the soils (Bastida and Talavera 2002). Although CL has a less developed root system than CS (Martín Bolaños and Guinea López 1949), they are both shallow-rooted, which favours their good colonizing capacity in xeric and highly disturbed areas (Correia et al. 1992; Zunzunegui et al. 2005).

Measurements and sampling

\section{Litterfall}

Litterfall was assessed using litter traps $(1.5 \mathrm{~mm}$ mesh screen with $80 \times 80 \mathrm{~cm}^{2}$ collecting surface) placed under the canopy of 20 randomly selected shrubs of each species (elevated ca. $6 \mathrm{~cm}$ above the ground). Litter collections were made fortnightly from August 2004 until December 2006, and were sorted into leaves, branches and twigs, flowers, and fruits. After drying $\left(80^{\circ} \mathrm{C}\right)$, the litterfall components were weighed. Litterfall samples of each organ (leaves, branches and twigs, flowers, and fruits) collected from traps under the same species and sampling date were pooled, resulting in one sample per organ and collection date, and a subsample was taken for chemical analysis.

\section{Leaf litter decomposition}

Leaf litter decomposition was studied over a 4-year period, using the litter bag method. Freshly abscised 
leaves collected from litter traps during June-July 2003, the peak period of litterfall, were selected. After thoroughly mixed to provide uniform leaf litter for each species, subsamples of approximately $2.5 \mathrm{~g}$ (dry weight) of leaf material were placed in $13 \times 13 \mathrm{~cm}^{2}$ litter bags ( $1 \mathrm{~mm}$ mesh size). Three-hundred litterbags from each species were randomly distributed on soil surface beneath shrub canopies, on October 2003. Fifteen litter bags of each species were retrieved at $2-$ 4 months intervals in the first 2 years and at 6-months intervals in the remaining period. The decomposing material from litterbags collected was dried $\left(80^{\circ} \mathrm{C}\right)$ and weighed separately to assess mass loss and subsamples were taken for $\mathrm{N}$ and $\mathrm{P}$ analysis.

\section{Bulk precipitation and throughfall}

Bulk precipitation and throughfall were sampled during 2005 and 2006, according to rain events, and were collected in glass funnel-type collectors with $450 \mathrm{~mL}$ capacity and ca. $8 \mathrm{~cm}$ diameter, fitted with mesh covers. Bulk precipitation was collected in four collectors placed in open areas, and throughfall in twelve collectors per species, randomly placed beneath the canopy of four shrubs (three collectors per shrub). Throughfall was measured on an 'event' basis, where a rainfall event commenced with the onset of rainfall and was considered complete when the canopy and bark were dry. After each rainfall event, containers were retrieved and replaced with a clean set (acid-washed and triple-rinsed with distilled water). Volumes of bulk precipitation and throughfall samples were recorded individually and $\mathrm{pH}$ was measured using glass electrodes. Water samples from collectors of the same collecting site (bulk precipitation, throughfall of CS and throughfall of CL) and sampling date were pooled, resulting in three water samples per event, and subsamples were frozen and stored for analysis purposes.

\section{Soil organic and mineral layers}

The necromass on soil surface was sampled every 2 months, from January 2005 until December 2006, beneath three individuals of each study species, randomly chosen. Samples of necromass collected under the canopy of each shrub were dried $\left(80^{\circ} \mathrm{C}\right)$ and weighed, and subsamples were taken for chemical analysis.
In the spring 2006, undisturbed samples for bulk density measurement were taken at $0-5$ and $5-10 \mathrm{~cm}$ soil depth, using cylinders with $5 \mathrm{~cm}$ diameter and $5 \mathrm{~cm}$ high; six samples were collected under each species canopies and 12 in shrub interspaces. To determine soil-water retention at different soil matric potential, 30 undisturbed samples were collected beneath shrubs and 30 in open areas, at both $0-5$ and $5-10 \mathrm{~cm}$ soil depth.

Soil samples (cores of $4.5 \mathrm{~cm}$ diameter) for chemical analysis were taken at $0-5,5-10,10-20$ and $20-30 \mathrm{~cm}$ depth in the spring 2006, underneath twelve shrubs of each study species and in twelve locations in open areas. Beneath the canopy of each shrub and in each open location were taken four samples, which were bulked in one composite sample. After air-dried, composite samples were sieved to $2 \mathrm{~mm}$.

\section{Laboratory procedures}

Samples of plant material (litterfall, decomposing leaf litter and necromass) were dried and ground to pass through a $1 \mathrm{~mm}$ mesh screen. Total $\mathrm{N}$ was determined using Kjeldhal digestion (Digestion System 40, Kjeltec Auto 1030 Analyzer). The $\mathrm{C}$ amount was calculated assuming an average $\mathrm{C}$ content of $50 \%$ of ash-free mass. The mineral elements $(\mathrm{Ca}, \mathrm{Mg}, \mathrm{K}$ and P) were determined after ashing $\left(6 \mathrm{~h}\right.$ at $\left.450^{\circ} \mathrm{C}\right)$ and taken up in $\mathrm{HCl}$. $\mathrm{Ca}, \mathrm{Mg}$ and $\mathrm{K}$ were determined by atomic absorption spectrophotometry (AAS). Concentration of $\mathrm{P}$ was measured colorimetrically by the molybdenum blue method.

Samples of bulk rain and throughfall were thawed and filtered for analysis of $\mathrm{N}-\mathrm{NO}_{3}{ }^{-}, \mathrm{N}-\mathrm{NH}_{4}{ }^{+}, \mathrm{P}_{-} \mathrm{PO}_{4}{ }^{3-}$, $\mathrm{S}_{-} \mathrm{SO}_{4}{ }^{2-}, \mathrm{Cl}^{-}, \mathrm{K}^{+}, \mathrm{Ca}^{2+}, \mathrm{Mg}^{2+}$ and $\mathrm{Na}^{+}$. The phenolnitroprussiate colorimetry method (Dorich and Nelson 1983) was used to determine the $\mathrm{N}_{-} \mathrm{NH}_{4}{ }^{+}$concentration. $\mathrm{N}_{-} \mathrm{NO}_{3}{ }^{-}, \mathrm{Cl}^{-}$and $\mathrm{S}_{-} \mathrm{SO}_{4}{ }^{2-}$ were determined by capillary electrophoresis with a Millipore Water Capillary Ion Analyzes, after filtration and ultrasound degasification. Concentrations of $\mathrm{K}^{+}, \mathrm{Ca}^{2+}, \mathrm{Mg}^{2+}$, $\mathrm{Na}^{+}$and $\mathrm{P}_{-} \mathrm{PO}_{4}{ }^{3-}$ were measured as for plant material.

Soil water retention at matric potentials of -10 and -33 $\mathrm{kPa}$ was obtained using a Pressure Plate Extractor and that of $-1,500 \mathrm{kPa}$ with a Ceramic Plate Extractor from Soil Moisture. Given the coarse soil texture, available soil water capacity was determined by the difference between water content at -10 and $-1,500 \mathrm{kPa}$, corresponding approximately to the 
content at field capacity and at wilting point (Brady and Weil 1999).

The soil chemical properties were determined on the fine fraction $(<2 \mathrm{~mm})$ of air-dried samples. Soil $\mathrm{pH}$ was determined potentiometrically in distilled water (soil: water ratio $1: 2.5$ ). Total $\mathrm{N}$ was determined as above. Particulate soil organic matter (POM) was assessed following the methodology described by Bruckert (1979), determining organic matter in soil particles greater than $50 \mu \mathrm{m}$, after shaking and sieving the sample in water. The $\mathrm{C}$ content of both the total soil organic matter and POM was determined by wet oxidation. Extractable P and $\mathrm{K}$ were extracted using the Egnér-Riehm method (Riehm 1958) and the exchangeable base cations were extracted by $1 \mathrm{M} \mathrm{NH}_{4} \mathrm{OAc}$, adjusted at $\mathrm{pH} 7.0$ (Houba et al. 1994). The $\mathrm{Ca}^{2+}, \mathrm{Mg}^{2+}, \mathrm{Na}^{+}, \mathrm{K}^{+}$and $\mathrm{P}$ of extracts were measured as above.

Data analysis

The decomposition rates of leaves were calculated, after 1, 2 and 4 years, by the single exponential model (Olson 1963):

$Y=e^{-k t}$,

where $Y$ is the proportion of initial mass remaining at the time $t$ (in years), and $k$ is the decomposition rate.

The degree of enrichment or depletion of nutrients in throughfall was calculated according to Gordon et al. (2000):

Enrichment/depletion ratio $=$ (nutrient concentration in throughfall-nutrient concentration in bulk rainfall) / nutrient concentration in bulk rainfall

Differences in litterfall amounts and nutrient concentrations, in potential return of bio-elements through litterfall and through bulk precipitation and throughfall, between species and years and their interaction, were determined with two-way ANOVA (GLM). If significant differences occurred in the return of bio-elements through bulk precipitation and throughfall, Scheffé tests for multiple comparisons were used to identify significant differences between species in each year. Two sample Student's $t$-tests were performed to assess differences between the two species regarding remaining organic matter (OM), $\mathrm{N}$ and $\mathrm{P}$ during leaf decomposition, and necromass, nutrient concentrations and nutrient amounts beneath canopies. Differences in soil bulk density and in soil water retention, between locations, were determined for each depth with two sample Student's $t$-tests. Differences in chemical characteristics of soil mineral layers, beneath shrub canopies and out of their influence, were determined with one-way ANOVA and Scheffé tests for multiple comparisons, in each depth. Some of the data were transformed (natural log or square root) for homogeneity of variances. Analyses were performed using SPSS 16.0 (Apache Software Found., USA).

\section{Results}

Litterfall production

Annual leaf litterfall was significantly higher for CL than for CS (Fig. 1 and Table 1). In contrast, reproductive components were higher in litterfall of CS than in that of CL. In the second year of study a decrease was observed in flower litterfall of CL. Leaf litter was the main component of litterfall, representing $67-69 \%$ of the total for CS and $86-87 \%$ for CL. Reproductive organs were $27-30 \%$ and $10-11 \%$, respectively, whereas twigs and branches were only $3-5 \%$ and $2-4 \%$.

A similar seasonal variation pattern was observed for leaf fall of both study species (Fig. 2). Maximum oc-

Fig. 1 Annual litterfall $(\mathrm{Mg}$

DM ha ${ }^{-1}$ year $^{-1}$ ) of $C$. salviifolius (CS) and $C$. ladanifer (CL) (total litterfall-TL; leaf litterfall-LFL; twig and branch litterfallTBL; flower litterfall-FLL; fruit litterfall-FTL). Bars represent the standard error of the mean $(n=20)$
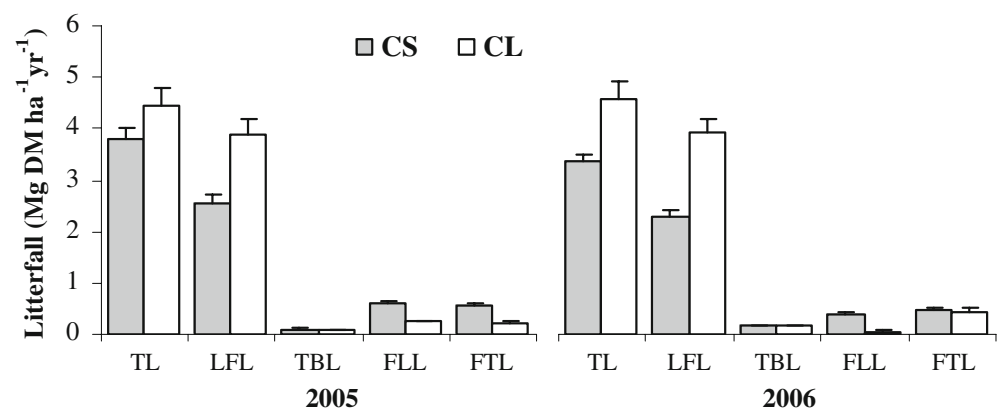
Table 1 Results of two-way ANOVA analysis for the effects of species, year and their interaction on annual total litterfall (TL), leaf litterfall (LFL), twig and branch litterfall (TBL), flower litterfall (FLL) and fruit litterfall (FTL) of C. salviifolius (CS) and C. ladanifer (CL), in 2005 and 2006

\begin{tabular}{llllll}
\hline & TL & LFL & TBL & FLL & FTL \\
\hline Species & $F=9.88^{* *}$ & $F=45.12^{* * *}$ & $F=0.05 \mathrm{~ns}$ & $F=179.96^{* * *}$ & $F=18.24^{* * *}$ \\
Year & $F=0.32 \mathrm{~ns}$ & $F=0.28 \mathrm{~ns}$ & $F=16.48^{* * *}$ & $F=60.44^{* * *}$ & $F=3.41 \mathrm{~ns}$ \\
Interaction & $F=1.40 \mathrm{~ns}$ & $F=0.73 \mathrm{~ns}$ & $F=0.01 \mathrm{~ns}$ & $F=5.46^{*}$ & $F=13.17 * *$ \\
\hline
\end{tabular}

$n s$ not significant

$* * * P<0.001$

$* * 0.001 \leq P<0.01$

$* 0.01 \leq P<0.05$
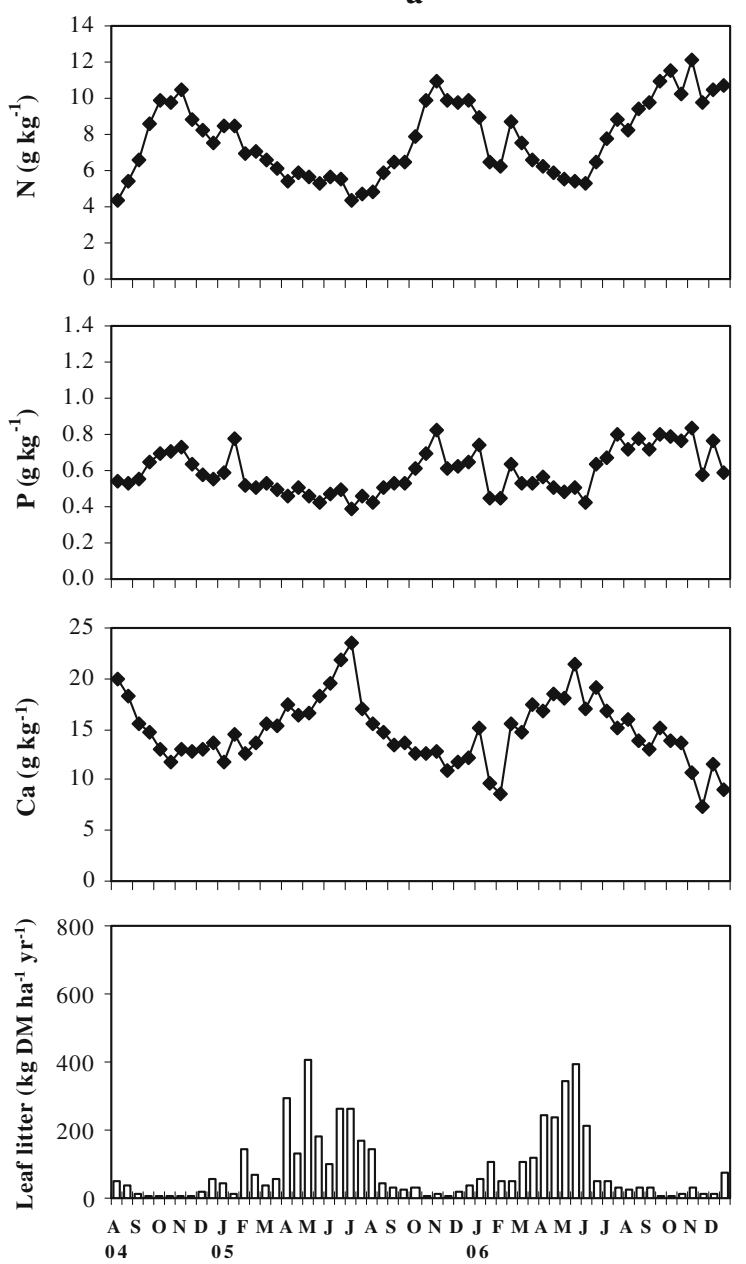

b
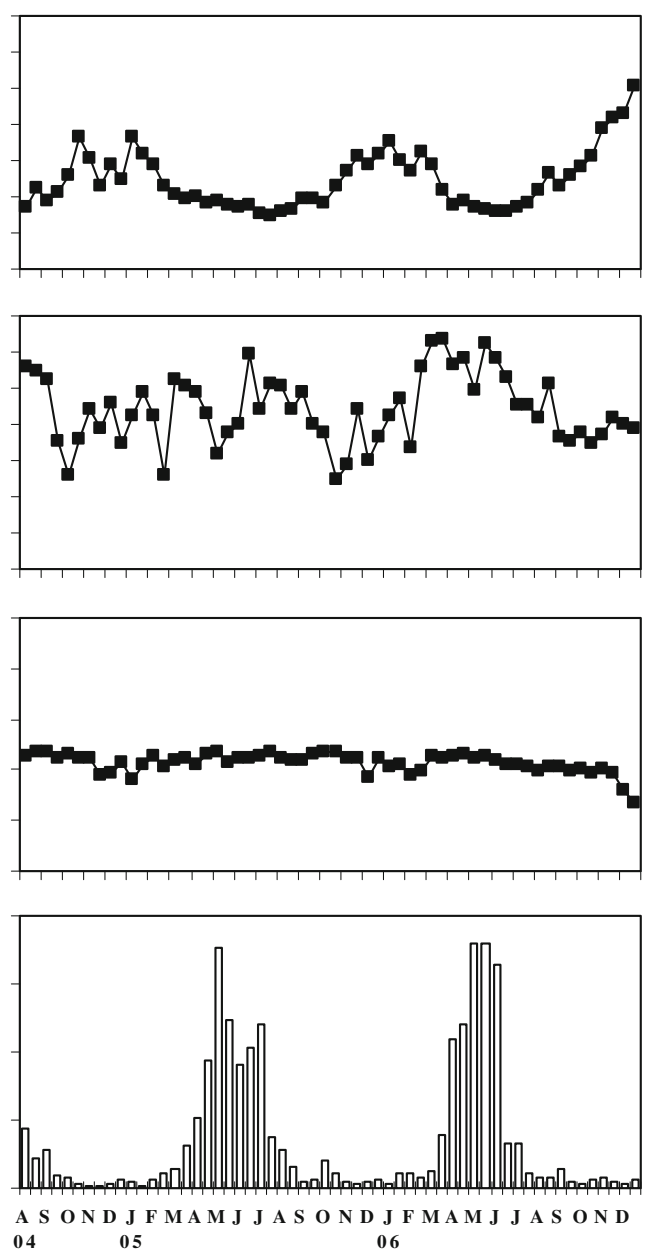

Fig. 2 Seasonal variation of leaf litter $\left(\mathrm{kg} \mathrm{DM} \mathrm{ha}^{-1} \mathrm{year}^{-1}\right)$ and $\mathrm{N}, \mathrm{P}, \mathrm{K}, \mathrm{Ca}$ and $\mathrm{Mg}$ concentrations $\left(\mathrm{g} \mathrm{kg}^{-1}\right)$, in C. salviifolius (a) and C. ladanifer (b) 
curred from April to July (68\% to $85 \%$ of total annual) and minimum from September to December. As leaf fall was the major component of litterfall, it closely coupled the seasonal pattern of total litter production.

Nutrient concentrations in litterfall

Leaf litterfall of CS showed higher concentrations of $\mathrm{N}$, $\mathrm{Ca}$ and $\mathrm{Mg}$, whereas $\mathrm{P}$ concentration was higher in that of CL (Table 2). Leaf C-to-N ratio was also higher for $\mathrm{CL}$ than for $\mathrm{CS}$. $\mathrm{K}$ concentration did not differ significantly between the two species. Concentrations of $\mathrm{K}$ and $\mathrm{Mg}$ in twigs and branches of CS were higher than in those of $\mathrm{CL}$ (Table 2), whereas $\mathrm{P}$ and $\mathrm{Ca}$ concentrations were higher in $\mathrm{CL}$ than in CS. Following the general trend, $\mathrm{N}, \mathrm{P}, \mathrm{Ca}$ and $\mathrm{Mg}$ concentrations in reproductive organs were higher in $\mathrm{CS}$ than in $\mathrm{CL}$, excepting $\mathrm{P}$ concentration in flower litterfall.

Concentrations of $\mathrm{N}$ in leaf litterfall showed the same seasonal variation pattern in both species. Maximum concentrations were observed during autumn and winter and minimum in late-spring and summer, coinciding with peak leaf fall (Fig. 2). Seasonal variation of $\mathrm{P}$ in CS leaf litterfall was similar to that of $\mathrm{N}$, but in CL it strongly differed, with strong variations along the year as observed for $\mathrm{K}$ (data not shown). In contrast to $\mathrm{N}$ and $\mathrm{P}, \mathrm{Ca}$ concentrations showed little variation throughout the year for CL,
Table 2 Nutrient concentrations $\left(\mathrm{g} \mathrm{kg}^{-1}\right)$ and C-to-N ratios in leaf (LFL), twig and branch (TBL), flower (FLL) and fruit (FTL) litterfall of $C$. salviifolius (CS) and $C$. ladanifer (CL), in 2005 and 2006

Values are weighted means ( $n=24$ for leaves and $n=12$ for other components) $n s$ not significant

$* * * P<0.001$

$* * 0.001 \leq P<0.01$

$* 0.01 \leq P<0.05$

\begin{tabular}{|c|c|c|c|c|c|c|c|}
\hline & CS-05 & CL-05 & CS-06 & CL-06 & Species & Year & Interaction \\
\hline \multicolumn{8}{|l|}{$\mathrm{N}$} \\
\hline LFL & 5.76 & 3.63 & 6.59 & 3.74 & $F=62.34 * * *$ & $F=8.21^{* *}$ & $F=0.00 \mathrm{~ns}$ \\
\hline TBL & 5.80 & 5.50 & 5.65 & 5.56 & $F=3.35 \mathrm{~ns}$ & $F=1.57 \mathrm{~ns}$ & $F=0.73 \mathrm{~ns}$ \\
\hline FLL & 7.88 & 4.69 & 8.77 & 6.53 & $F=5.28^{*}$ & $F=3.66 \mathrm{~ns}$ & $F=0.03 \mathrm{~ns}$ \\
\hline FTL & 6.14 & 4.65 & 6.13 & 3.94 & $F=29.51 * * *$ & $F=12.80^{* *}$ & $F=13.79 * *$ \\
\hline \multicolumn{8}{|l|}{ C-to-N } \\
\hline LFL & 76 & 121 & 64 & 105 & $F=61.85^{* * *}$ & $F=8.03 * *$ & $F=0.00 \mathrm{~ns}$ \\
\hline TBL & 86 & 91 & 89 & 91 & $F=6.26^{*}$ & $F=2.46 \mathrm{~ns}$ & $F=1.60 \mathrm{~ns}$ \\
\hline FLL & 66 & 106 & 50 & 76 & $F=23.58 * * *$ & $F=11.26^{* *}$ & $F=1.11 \mathrm{~ns}$ \\
\hline FTL & 78 & 88 & 78 & 124 & $F=78.03 * * *$ & $F=31.30^{* * *}$ & $F=31.01 * * *$ \\
\hline \multicolumn{8}{|l|}{$\mathrm{P}$} \\
\hline LFL & 0.48 & 0.85 & 0.54 & 1.10 & $F=90.16^{* * *}$ & $F=9.73 * *$ & $F=0.11 \mathrm{~ns}$ \\
\hline TBL & 0.43 & 0.44 & 0.43 & 0.47 & $F=8.81 * *$ & $F=0.66 \mathrm{~ns}$ & $F=0.22 \mathrm{~ns}$ \\
\hline FLL & 1.07 & 0.79 & 1.16 & 1.07 & $F=3.10 \mathrm{~ns}$ & $F=5.40^{*}$ & $F=0.24 \mathrm{~ns}$ \\
\hline FTL & 0.62 & 0.48 & 0.59 & 0.36 & $F=21.74 * * *$ & $F=12.75^{* *}$ & $F=11.58^{* *}$ \\
\hline \multicolumn{8}{|l|}{$\mathrm{K}$} \\
\hline LFL & 3.69 & 3.34 & 4.04 & 3.52 & $F=2.01 \mathrm{~ns}$ & $F=0.01 \mathrm{~ns}$ & $F=0.10 \mathrm{~ns}$ \\
\hline TBL & 3.50 & 1.42 & 2.30 & 1.46 & $F=9.78^{* *}$ & $F=1.28 \mathrm{~ns}$ & $F=1.74 \mathrm{~ns}$ \\
\hline FLL & 7.99 & 6.79 & 7.45 & 7.72 & $F=0.02 \mathrm{~ns}$ & $F=0.01 \mathrm{~ns}$ & $F=0.12 \mathrm{~ns}$ \\
\hline FTL & 3.88 & 3.55 & 3.33 & 2.09 & $F=1.99 \mathrm{~ns}$ & $F=1.24 \mathrm{~ns}$ & $F=0.51 \mathrm{~ns}$ \\
\hline \multicolumn{8}{|l|}{$\mathrm{Ca}$} \\
\hline LFL & 17.43 & 11.22 & 16.78 & 11.01 & $F=69.97 * * *$ & $F=2.08 \mathrm{~ns}$ & $F=0.01 \mathrm{~ns}$ \\
\hline TBL & 6.84 & 10.64 & 6.84 & 11.30 & $F=262.25^{* * *}$ & $F=2.75 \mathrm{~ns}$ & $F=4.33^{*}$ \\
\hline FLL & 7.36 & 2.54 & 7.73 & 2.22 & $F=23.52 * *$ & $F=0.09 \mathrm{~ns}$ & $F=0.16 \mathrm{~ns}$ \\
\hline FTL & 7.57 & 4.25 & 6.86 & 3.63 & $F=336.39 * * *$ & $F=6.32 *$ & $F=0.02 \mathrm{~ns}$ \\
\hline \multicolumn{8}{|l|}{$\mathrm{Mg}$} \\
\hline LFL & 3.02 & 2.15 & 3.04 & 2.44 & $F=64.23 * * *$ & $F=0.24 \mathrm{~ns}$ & $F=0.28 \mathrm{~ns}$ \\
\hline TBL & 1.11 & 0.81 & 1.10 & 0.80 & $F=91.67 * * *$ & $F=0.07 \mathrm{~ns}$ & $F=0.10 \mathrm{~ns}$ \\
\hline FLL & 2.06 & 1.01 & 2.18 & 0.73 & $F=12.70^{* *}$ & $F=0.02 \mathrm{~ns}$ & $F=0.23 \mathrm{~ns}$ \\
\hline FTL & 1.35 & 0.97 & 1.29 & 0.80 & $F=88.58^{* * *}$ & $F=5.88^{*}$ & $F=4.99^{*}$ \\
\hline
\end{tabular}


Table 3 Annual potential return of bio-elements $\left(\mathrm{kg} \mathrm{ha}^{-1}\right.$ year $\left.^{-1}\right)$ through litterfall of $C$. salviifolius (CS) and C. ladanifer (CL), in 2005 and 2006

\begin{tabular}{|c|c|c|c|c|c|c|c|}
\hline & CS-05 & CL-05 & CS-06 & CL-06 & Species & Year & Interaction \\
\hline $\mathrm{N}$ & $23.3 \pm 1.4$ & $16.7 \pm 1.3$ & $22.5 \pm 1.1$ & $17.7 \pm 1.3$ & $F=19.71 * * *$ & $F=0.01 \mathrm{~ns}$ & $F=0.44 \mathrm{~ns}$ \\
\hline $\mathrm{P}$ & $2.2 \pm 0.1$ & $3.6 \pm 0.3$ & $2.1 \pm 0.1$ & $4.6 \pm 0.3$ & $F=85.37 * * *$ & $F=1.65 \mathrm{~ns}$ & $F=5.82 *$ \\
\hline K & $16.6 \pm 1.0$ & $15.5 \pm 1.2$ & $14.3 \pm 0.7$ & $15.4 \pm 1.1$ & $F=0.00 \mathrm{~ns}$ & $F=1.40 \mathrm{~ns}$ & $F=1.19 \mathrm{~ns}$ \\
\hline $\mathrm{Ca}$ & $53.5 \pm 3.2$ & $46.0 \pm 3.6$ & $46.2 \pm 2.3$ & $46.7 \pm 3.5$ & $F=1.21 \mathrm{~ns}$ & $F=1.09 \mathrm{~ns}$ & $F=1.60 \mathrm{~ns}$ \\
\hline $\mathrm{Mg}$ & $9.8 \pm 0.6$ & $8.9 \pm 0.7$ & $8.7 \pm 0.4$ & $10.1 \pm 0.7$ & $F=0.19 \mathrm{~ns}$ & $F=0.02 \mathrm{~ns}$ & $F=3.53 \mathrm{~ns}$ \\
\hline
\end{tabular}

Values are mean \pm SE for 20 shrubs

$n s$ not significant

$* * * P<0.001$

$* 0.01 \leq P<0.05$

whereas a strong variation was observed in values of CS, with maximum values occurring during peak litterfall (Fig. 2). Variation of $\mathrm{K}$ and $\mathrm{Mg}$ concentrations throughout the year was similar in both species.

Annual potential return of bio-elements through litterfall

Annual potential return of $\mathrm{N}$ to the soil through litterfall of CS (22.9 kg N ha ${ }^{-1}$ year $\left.^{-1}\right)$ was 1.3 times that of CL $\left(17.2 \mathrm{~kg} \mathrm{~N} \mathrm{ha}^{-1}\right.$ year $\left.^{-1}\right)$; in contrast, the potential return of P by CL (4.1 kg P ha ${ }^{-1}$ year $^{-1}$ ) was twice that by CS $\left(2.1 \mathrm{~kg} \mathrm{P} \mathrm{ha}^{-1}\right.$ year $\left.^{-1}\right)$. The return of K (15.4 and 15.5 $\mathrm{kg} \mathrm{P} \mathrm{ha}{ }^{-1}$ year $^{-1}$, respectively), Ca (49.8 and $46.4 \mathrm{~kg}$ $\mathrm{Ca} \mathrm{ha}^{-1}$ year $^{-1}$ ) and $\mathrm{Mg}$ (9.2 and $9.5 \mathrm{~kg} \mathrm{Mg} \mathrm{ha}{ }^{-1}$ year $^{-1}$ ) were similar in both species (Table 3).

Leaf litter was responsible for the return of $63-68 \%$ of N, $57 \%$ of P, $57-65 \%$ of K, $83-84 \%$ of $\mathrm{Ca}$ and 79 $80 \%$ of $\mathrm{Mg}$, in CS (Table 3). In CL these proportions were even higher: 83-84\%, 92-93\%, 84-90\%, 93-95\% and $94-95 \%$, respectively. The variation pattern of nutrient return through leaf litterfall generally followed that of leaf litterfall (Fig. 2), the highest amounts being observed during spring and early summer (66 to $79 \%$ of the total for CS and 79 to $85 \%$ for CL).

\section{Leaf litterfall decomposition}

Leaf decomposition was faster for CS than for CL. The decomposition rate $(k)$ increased from -0.68 after $1-y r$ to -0.87 after 4-years in CS, while in CL values of $k$ were of the same magnitude $(-0.44$ to -0.49$)$ along all the study period (Table 4). At the end of the study, OM remaining was 3 and $17 \%$, respectively.

Nitrogen release from decomposing leaf litter was also significantly faster $(P<0.05)$ for $\mathrm{CS}$ than for $\mathrm{CL}$ (Fig. 3). After an initial immobilization phase (1-yr for CS and 3-yr for CL) N release was observed ( 80 and $78 \%$ of $\mathrm{N}$ remaining), coinciding with similar values of the C-to-N ratio in the litter of both species (36 and 34). The remaining proportions after 1,538 days were 8 and $58 \%$ of the initial, respectively. In

Table 4 Remaining proportions (\%) of organic matter (OM), decomposition rates $\left(k\right.$ year $\left.^{-1}\right)$, calculated with single exponential model $\left(Y=e^{-k t}\right)$, after 1,2 and 4 years and coefficients of

determination of the model $\left(r^{2}\right)$, for decomposing leaf litter of $C$. salviifolius (CS) and C. ladanifer (CL)

\begin{tabular}{|c|c|c|c|c|c|c|c|c|c|}
\hline & \multicolumn{3}{|l|}{$1-y r$} & \multicolumn{3}{|l|}{$2-y r$} & \multicolumn{3}{|l|}{ 4-yr } \\
\hline & OM (\%) & $k$ year $^{-1}$ & $r^{2}$ & OM (\%) & $k$ year $^{-1}$ & $r^{2}$ & OM (\%) & $k$ year $^{-1}$ & $r^{2}$ \\
\hline $\mathrm{CS}$ & $60 \pm 3.9$ & $0.68^{\mathrm{a}}$ & $0.95 * * *$ & $21 \pm 2.5^{\mathrm{a}}$ & $0.79^{\mathrm{a}}$ & $0.98 * * *$ & $3 \pm 0.4^{\mathrm{a}}$ & $0.87^{\mathrm{a}}$ & $0.98 * * *$ \\
\hline $\mathrm{CL}$ & $67 \pm 1.0$ & $0.49^{\mathrm{b}}$ & $0.91 * *$ & $40 \pm 1.3^{b}$ & $0.45^{\mathrm{b}}$ & $0.97 * * *$ & $17 \pm 2.6^{\mathrm{b}}$ & $0.44^{\mathrm{b}}$ & $0.98 * * *$ \\
\hline
\end{tabular}

MO values are mean \pm SE $(n=15)$. Means in the same column with different letters are significantly different $(P<0.05)$

$* * 0.001 \leq P<0.01$

$* * * P<0.001$ 


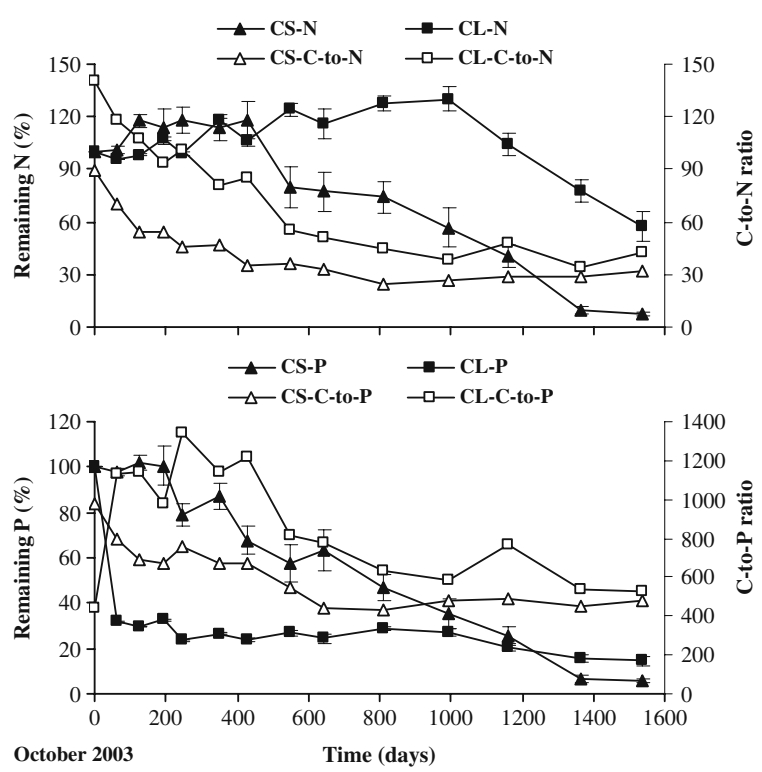

Fig. 3 Remaining proportion (\% of the initial) of $\mathrm{N}$ and $\mathrm{P}$, and C-to-N and C-to-P ratios during decomposition of leaf litter of C. salviifolius $(\mathrm{CS})$ and $C$. ladanifer $(\mathrm{CL})$. Bars represent the standard error of the mean $(n=15)$ contrast to $\mathrm{N}$, initial $\mathrm{P}$ release was significantly faster $(P<0.001)$ for CL $(68 \%$ after 65 days $)$ than for CS ( $2 \%$ after the same period). Nevertheless, the remaining proportions at the end of the study period were $15 \%$ for CL and $6 \%$ for CS (Fig. 3).

Potential return of bio-elements through bulk rainfall and throughfall

In 2005, eight rainfall events were recorded and the total gross rainfall was $396 \mathrm{~mm}_{\text {year }}{ }^{-1}$, while in 2006, there were 16 events and the total rainfall amounted to $702 \mathrm{~mm}$ year $^{-1}$. Throughfall proportions were $61 \%$ of bulk rainfall for CS and $79 \%$ for CL.

A general trend to higher nutrient concentrations in throughfall relative to bulk rainfall was observed. The highest enrichment ratios were determined for $\mathrm{K}^{+}(6.1$ for $\mathrm{CS}$ and 7.1 for $\mathrm{CL}), \mathrm{Mg}^{2+}$ (1.6 and 1.9) and $\mathrm{Ca}^{2+}$ (1.4 and 2.2). The magnitude of $\mathrm{P}_{-} \mathrm{PO}_{4}{ }^{3-}, \mathrm{S}_{-} \mathrm{SO}_{4}{ }^{2-}$ and $\mathrm{Cl}^{-}$ratios was similar in the two species $(0.6-0.7$, 0.3 and 1.1-1.3, respectively). In contrast to the general trend, depletion of $\mathrm{N}_{-} \mathrm{NO}_{3}{ }^{-}$was observed in throughfall of both species $(-0.14$ for CS and -0.01 for CL) in the wetter year (2006), while $\mathrm{N}_{-} \mathrm{NH}_{4}{ }^{+}$was

Table 5 Annual potential return of $\mathrm{H}$ and bio-elements $\left(\mathrm{kg} \mathrm{ha}^{-1}\right.$ year $\left.{ }^{-1}\right)$ through bulk rainfall (BR) and throughfall under $C$. salviifolius (TFCS) and C. ladanifer (TFCL)

\begin{tabular}{|c|c|c|c|c|c|c|c|c|c|}
\hline & $\mathrm{BR}$ & TFCS & TFCL & $\mathrm{BR}$ & TFCS & TFCL & $\mathrm{F}$ values & & \\
\hline & 2005 & & & 2006 & & & $\mathrm{Sp}$ & $\mathrm{Yr}$ & $\mathrm{Sp} \times \mathrm{Yr}$ \\
\hline $\mathrm{H}^{+}$ & n.d. & n.d. & n.d. & $0.005 \pm 0.0^{\mathrm{a}}$ & $0.001 \pm 0.0^{\mathrm{b}}$ & $0.015 \pm 0.01^{\mathrm{c}}$ & $385.11 * * *$ & - & - \\
\hline $\mathrm{N}-\mathrm{NO}_{3}{ }^{-}$ & $0.5 \pm 0.0^{\mathrm{a}}$ & $0.7 \pm 0.0^{\mathrm{ab}}$ & $0.8 \pm 0.0^{\mathrm{b}}$ & $3.2 \pm 0.0^{\mathrm{a}}$ & $1.5 \pm 0.1^{\mathrm{b}}$ & $2.0 \pm 0.1^{\mathrm{c}}$ & $9.52 * * *$ & $433.88 * * *$ & $22.55 * * *$ \\
\hline $\mathrm{N}-\mathrm{NH}_{4}{ }^{+}$ & $0.3 \pm 0.0^{\mathrm{a}}$ & $0.2 \pm 0.0^{\mathrm{b}}$ & $0.1 \pm 0.0^{\mathrm{c}}$ & $0.2 \pm 0.0^{\mathrm{a}}$ & $0.1 \pm 0.0^{\mathrm{b}}$ & $0.2 \pm 0.0^{\mathrm{a}}$ & $37.58 * * *$ & $48.43^{* * *}$ & $38.66^{* * *}$ \\
\hline $\mathrm{P}-\mathrm{PO}_{4}{ }^{3-}$ & $0.1 \pm 0.0^{\mathrm{a}}$ & $0.1 \pm 0.0^{\mathrm{a}}$ & $0.1 \pm 0.0^{\mathrm{b}}$ & $0.2 \pm 0.0^{\mathrm{a}}$ & $0.1 \pm 0.0^{\mathrm{b}}$ & $0.2 \pm 0.0^{\mathrm{a}}$ & $23.36 * * *$ & $116.56^{* * *}$ & $10.81 * * *$ \\
\hline $\mathrm{S}-\mathrm{SO}_{4}{ }^{2-}$ & $1.7 \pm 0.0^{\mathrm{a}}$ & $1.7 \pm 0.1^{\mathrm{a}}$ & $2.0 \pm 0.1^{\mathrm{a}}$ & $4.5 \pm 0.0^{\mathrm{a}}$ & $2.5 \pm 0.1^{\mathrm{b}}$ & $3.6 \pm 0.3^{\mathrm{a}}$ & $14.36^{* * *}$ & $131.70^{* * *}$ & $9.41 * * *$ \\
\hline $\mathrm{Cl}^{-}$ & $5.7 \pm 0.2^{\mathrm{a}}$ & $8.7 \pm 0.5^{\mathrm{b}}$ & $13.1 \pm 0.8^{\mathrm{c}}$ & $27.6 \pm 0.2^{\mathrm{a}}$ & $29.5 \pm 1.8^{\mathrm{a}}$ & $39.0 \pm 3.0^{\mathrm{b}}$ & $32.56^{* * *}$ & $476.53 * * *$ & $4.95^{*}$ \\
\hline $\mathrm{K}^{+}$ & $0.8 \pm 0.0^{\mathrm{a}}$ & $3.5 \pm 0.2^{\mathrm{b}}$ & $4.3 \pm 0.3^{\mathrm{c}}$ & $2.2 \pm 0.0^{\mathrm{a}}$ & $9.0 \pm 0.5^{\mathrm{b}}$ & $14.6 \pm 1.0^{\mathrm{c}}$ & $270.00 * * *$ & $353.43 * * *$ & $3.22 \mathrm{~ns}$ \\
\hline $\mathrm{Ca}^{2+}$ & $3.9 \pm 0.1^{\mathrm{a}}$ & $4.0 \pm 0.2^{\mathrm{a}}$ & $5.6 \pm 0.3^{\mathrm{b}}$ & $3.5 \pm 0.0^{\mathrm{a}}$ & $6.3 \pm 0.3^{\mathrm{b}}$ & $10.9 \pm 0.8^{\mathrm{c}}$ & $59.82 * * *$ & $37.29 * * *$ & $12.17 * * *$ \\
\hline $\mathrm{Mg}^{2+}$ & $0.7 \pm 0.0^{\mathrm{a}}$ & $1.3 \pm 0.1^{\mathrm{b}}$ & $1.7 \pm 0.1^{\mathrm{c}}$ & $1.6 \pm 0.0^{\mathrm{a}}$ & $2.0 \pm 0.1^{\mathrm{a}}$ & $3.2 \pm 0.2^{\mathrm{b}}$ & $60.41 * * *$ & $124.42 * * *$ & $4.40^{*}$ \\
\hline $\mathrm{Na}^{+}$ & $4.1 \pm 0.1^{\mathrm{a}}$ & $3.9 \pm 0.2^{\mathrm{a}}$ & $4.7 \pm 0.3^{\mathrm{a}}$ & $13.7 \pm 0.1^{\mathrm{a}}$ & $9.5 \pm 0.6^{\mathrm{b}}$ & $11.5 \pm 0.8^{\mathrm{ab}}$ & $7.77 * *$ & $295.91 * * *$ & $2.13 \mathrm{~ns}$ \\
\hline
\end{tabular}

Values are mean \pm SE ( $n=4$ for bulk rainfall; $n=12$ for throughfall)

Significant differences between locations in each year are indicated (Scheffé tests) by different letters

$n d$ not determined, $n s$ not significant

$* * * P<0.001$

** $0.001 \leq P<0.01$

$* 0.01 \leq P<0.05$ 
Table 6 Necromass $\left(\mathrm{Mg} \mathrm{DM} \mathrm{ha}{ }^{-1}\right)$, organic matter content $\left(\mathrm{Mg} \mathrm{OM} \mathrm{ha}{ }^{-1}\right)$ and weighted mean nutrient concentrations $\left(\mathrm{g} \mathrm{kg}^{-1}\right)$ beneath C. salviifolius (BCS) and C. ladanifer (BCL) canopies

\begin{tabular}{|c|c|c|c|c|c|c|c|}
\hline & $\mathrm{DM}$ & $\mathrm{OM}$ & $\mathrm{N}$ & $\mathrm{P}$ & $\mathrm{K}$ & $\mathrm{Ca}$ & $\mathrm{Mg}$ \\
\hline BCS & $1.9 \pm 0.2^{\mathrm{a}}$ & $1.5 \pm 0.1^{\mathrm{a}}$ & $6.81^{\mathrm{a}}$ & $0.57^{\mathrm{a}}$ & $2.25^{\mathrm{a}}$ & $12.81^{\mathrm{a}}$ & $2.14^{\mathrm{a}}$ \\
\hline BCL & $3.2 \pm 0.4^{b}$ & $2.7 \pm 0.3^{b}$ & $4.63^{b}$ & $0.48^{\mathrm{a}}$ & $1.82^{\mathrm{a}}$ & $12.08^{\mathrm{a}}$ & $1.92^{\mathrm{a}}$ \\
\hline
\end{tabular}

Values are mean \pm SE $(n=12)$. Means in the same column with different letters are significantly different $(P<0.05)$

depleted in throughfall of CL in $2005(-0.55)$ and in that of CS in $2006(-0.06)$.

In the dry year (Table 5), the return of $\mathrm{N}^{-\mathrm{NO}_{3}}{ }^{-}$was higher by $\mathrm{CL}$ throughfall than by bulk rainfall. In contrast, the return of $\mathrm{N}_{-} \mathrm{NH}_{4}{ }^{+}$was significantly higher by bulk rainfall than by throughfall, but the amount was significantly higher under CS than under CL. For $\mathrm{P}_{-} \mathrm{PO}_{4}{ }^{3-}, \mathrm{Cl}^{-}, \mathrm{K}^{+}, \mathrm{Ca}^{2+}$ and $\mathrm{Mg}^{2+}$, the highest return was observed under $\mathrm{CL}$. In the wet year, the return of $\mathrm{N}_{-} \mathrm{NO}_{3}{ }^{-}, \mathrm{N}-\mathrm{NH}_{4}{ }^{+}, \mathrm{P}_{-} \mathrm{PO}_{4}{ }^{3-}$ and $\mathrm{S}_{-} \mathrm{SO}_{4}{ }^{2-}$ was significantly higher by bulk rainfall than by $\mathrm{CS}$ throughfall; for CL this trend was only observed for $\mathrm{N}^{-\mathrm{NO}_{3}}{ }^{-}$. Potential return of bio-elements under CL was higher than under $\mathrm{CS}$. In what concerns $\mathrm{H}^{+}$, amounts observed under CL shrubs were higher than in bulk rainfall, whereas those under CS were lower.

\section{Soil characteristics}

Necromass was significantly higher under CL than under CS canopies (Table 6). $\mathrm{N}$ concentration was higher in necromass of CS than in that of CL, while P, K, Ca and

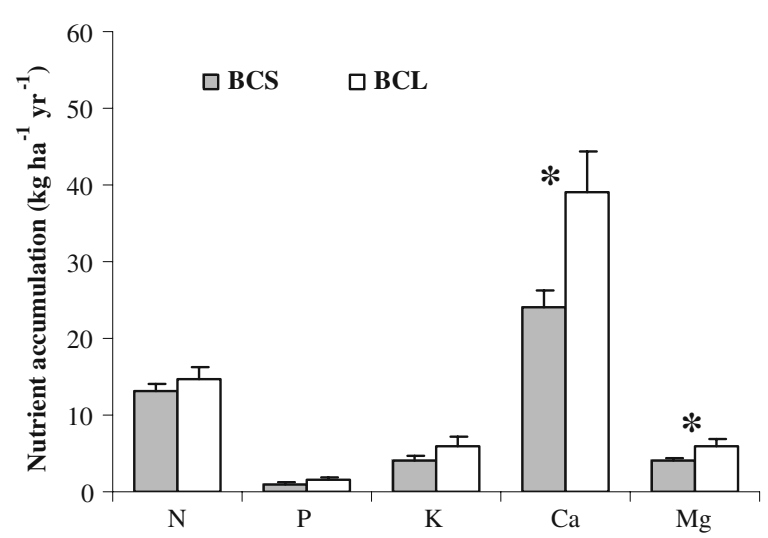

Fig. 4 Amounts $\left(\mathrm{kg} \mathrm{ha}^{-1}\right.$ year $\left.^{-1}\right)$ of $\mathrm{N}, \mathrm{P}, \mathrm{K}, \mathrm{Ca}$ and $\mathrm{Mg}$ in necromass, beneath $C$. salviifolius (BCS) and C. ladanifer (BCL) canopies. Bars represent the standard error of the mean $(n=12)$. Asterisks indicate values significantly different $(P<0.05)$
$\mathrm{Mg}$ concentrations were similar under both species. In agreement with necromass amounts and nutrient concentrations, $\mathrm{Ca}$ and $\mathrm{Mg}$ accumulation (Fig. 4) was higher in necromass under CL than under CS.

Soil bulk density in the $0-5 \mathrm{~cm}$ soil mineral layer was significantly lower beneath shrub canopies than in open areas. Values in the $5-10 \mathrm{~cm}$ soil layers were not significantly different (Table 7). Water retention by undisturbed soil beneath shrub species was not significantly different from that of soil from open areas, and therefore available soil water capacity was similar.

Both Cistus shrubs affected the chemical properties of soil mineral layers, but differences were mostly observed in the $0-5 \mathrm{~cm}$ top soil layer (Tables 8 and 9). In this layer, there was no significant difference for total organic C (SOC) and for C allocated to POM (Table 8). Nevertheless, as the proportion of organic $\mathrm{C}$ corresponding to the POM was predominant both beneath shrub canopy and in open areas and $\mathrm{N}$ concentration was similar among locations, at the same depth, C-to-N ratio was higher beneath shrub canopies (13.4-15.2) than at open spaces (11.3).

Table 7 Soil bulk density (SBD) $\left(\mathrm{g} \mathrm{cm}^{-3}\right)$, soil water retention $(\%, v / v)$ for different matric potential and available water (AW) $(\%, v / v)$, beneath shrub canopies (BC) and out of their influence (OC)

\begin{tabular}{|c|c|c|c|c|c|}
\hline \multirow{2}{*}{\multicolumn{2}{|c|}{ SBD }} & \multicolumn{3}{|c|}{ Soil-water retention } & \multirow[t]{2}{*}{ AW } \\
\hline & & $-10 \mathrm{kPa}$ & $-33 \mathrm{kPa}$ & $\begin{array}{l}-1,500 \\
\mathrm{kPa}\end{array}$ & \\
\hline \multicolumn{6}{|c|}{$0-5 \mathrm{~cm}$ depth } \\
\hline $\mathrm{BC}$ & $1.20 \pm 0.02^{\mathrm{a}}$ & $14.1 \pm 0.8$ & $12.6 \pm 0.5$ & $5.7 \pm 0.3$ & $8.4 \pm 0.6$ \\
\hline $\mathrm{OC}$ & $1.30 \pm 0.02^{b}$ & $13.8 \pm 0.3$ & $11.8 \pm 0.4$ & $5.3 \pm 0.2$ & $8.5 \pm 0.3$ \\
\hline \multicolumn{6}{|c|}{$5-10 \mathrm{~cm}$ depth } \\
\hline $\mathrm{BC}$ & $1.42 \pm 0.02$ & $13.1 \pm 0.8$ & $11.8 \pm 1.0$ & $5.9 \pm 0.3$ & $7.2 \pm 0.6$ \\
\hline $\mathrm{OC}$ & $1.46 \pm 0.03$ & $13.1 \pm 0.6$ & $11.3 \pm 0.2$ & $5.8 \pm 0.2$ & $7.3 \pm 0.5$ \\
\hline
\end{tabular}

Values are mean $\pm \operatorname{SE}(n=12)$. Means for the same parameter and depth followed by different letters are significantly different $(P<0.05)$ 
Table 8 Concentration of total carbon $\left(\mathrm{C}_{\mathrm{T}}\right), \mathrm{C}$ in particulate organic matter $\left(\mathrm{C}_{\mathrm{POM}}\right)$, total $\mathrm{N}$, and $\mathrm{C}-$ to- $\mathrm{N}$ ratio of the mineral soil layers, at $0-5,5-10,10-20$ and $20-30 \mathrm{~cm}$ depth, beneath C. salviifolius (BCS) and C. ladanifer (BCL) canopies, and in open areas (OP)

\begin{tabular}{|c|c|c|c|c|}
\hline \multirow[t]{2}{*}{ Loc } & $\mathrm{C}_{\mathrm{T}}$ & $\mathrm{C}_{\mathrm{POM}}$ & $\mathrm{N}$ & \multirow[t]{2}{*}{ C-to-N } \\
\hline & \multicolumn{3}{|l|}{$\mathrm{g} \mathrm{kg}^{-1}$} & \\
\hline \multicolumn{5}{|c|}{$0-5 \mathrm{~cm}$} \\
\hline BCS & $10.3 \pm 0.9^{\mathrm{a}}$ & $6.4 \pm 0.6^{\mathrm{a}}$ & $0.75 \pm 0.05^{\mathrm{a}}$ & $13.4 \pm 0.4^{\mathrm{a}}$ \\
\hline BCL & $11.4 \pm 1.2^{\mathrm{a}}$ & $7.2 \pm 0.9^{\mathrm{a}}$ & $0.77 \pm 0.09^{a}$ & $15.2 \pm 1.1^{\mathrm{a}}$ \\
\hline OP & $8.1 \pm 0.8^{\mathrm{a}}$ & $5.1 \pm 0.7^{\mathrm{a}}$ & $0.72 \pm 0.07^{\mathrm{a}}$ & $11.3 \pm 0.3^{\mathrm{b}}$ \\
\hline \multicolumn{5}{|c|}{$5-10 \mathrm{~cm}$} \\
\hline $\mathrm{BCS}$ & $6.0 \pm 0.3^{\mathrm{a}}$ & $2.8 \pm 0.2^{\mathrm{a}}$ & $0.47 \pm 0.02^{\mathrm{a}}$ & $13.0 \pm 0.3^{\mathrm{a}}$ \\
\hline BCL & $6.1 \pm 0.3^{\mathrm{a}}$ & $2.9 \pm 0.3^{\mathrm{a}}$ & $0.43 \pm 0.02^{\mathrm{a}}$ & $14.0 \pm 0.4^{\mathrm{a}}$ \\
\hline $\mathrm{OP}$ & $6.1 \pm 0.3^{\mathrm{a}}$ & $3.1 \pm 0.3^{\mathrm{a}}$ & $0.45 \pm 0.03^{\mathrm{a}}$ & $11.3 \pm 0.4^{\mathrm{b}}$ \\
\hline \multicolumn{5}{|c|}{$10-20 \mathrm{~cm}$} \\
\hline BCS & $4.1 \pm 0.3^{\mathrm{a}}$ & n.d. & $0.35 \pm 0.02^{\mathrm{a}}$ & $11.6 \pm 0.3^{\mathrm{ab}}$ \\
\hline $\mathrm{BCL}$ & $3.9 \pm 0.2^{\mathrm{a}}$ & n.d. & $0.30 \pm 0.02^{\mathrm{a}}$ & $12.9 \pm 0.6^{\mathrm{b}}$ \\
\hline OP & $4.0 \pm 0.2^{\mathrm{a}}$ & n.d. & $0.35 \pm 0.02^{\mathrm{a}}$ & $11.3 \pm 0.3^{\mathrm{a}}$ \\
\hline \multicolumn{5}{|c|}{$20-30 \mathrm{~cm}$} \\
\hline BCS & $3.0 \pm 0.3^{\mathrm{a}}$ & n.d. & $0.28 \pm 0.02^{\mathrm{a}}$ & $10.9 \pm 0.6^{\mathrm{a}}$ \\
\hline $\mathrm{BCL}$ & $2.8 \pm 0.2^{\mathrm{a}}$ & n.d. & $0.24 \pm 0.03^{\mathrm{a}}$ & $10.2 \pm 0.6^{\mathrm{a}}$ \\
\hline OP & $3.1 \pm 0.2^{\mathrm{a}}$ & n.d. & $0.32 \pm 0.03^{\mathrm{a}}$ & $9.8 \pm 0.5^{\mathrm{a}}$ \\
\hline
\end{tabular}

Values are mean $\pm \mathrm{SE}(n=12)$. nd not determined. Means for the same property and depth followed by different letters are significantly different $(P<0.05)$

Concentrations of exchangeable $\mathrm{Ca}^{2+}$ and sum of base cations under CS, and those of exchangeable $\mathrm{Mg}^{2+}$ and $\mathrm{K}^{+}$under CL were significantly higher than in barren spaces (Table 9). Extractable $\mathrm{K}$ was significantly higher in soil under both shrubs than in the open areas, effects being noted up to $-20 \mathrm{~cm}$ depth.

Soil $\mathrm{pH}\left(\mathrm{H}_{2} \mathrm{O}\right)$ beneath the shrubs was similar to that in open areas. For $\mathrm{pH}(\mathrm{KCl})$, values measured in soils under CS were higher than those in soils out of its influence (Table 9).

\section{Discussion}

Annual potential return of bio-elements

Leaf fall peaks were observed during late-spring and early-summer (in relation with increasing temperature and drought), which corroborate phenological observations on the study species (Simões et al. 2008). The amount of litterfall annually produced by CL (4.4-4.6 $\mathrm{Mg} \mathrm{DM} \mathrm{ha}{ }^{-1}$ year $^{-1}$ ) is higher than that reported by Nuñez-Olivera et al. (1993) for the same species (2.73.1 Mg DM ha ${ }^{-1}$ year $^{-1}$ ), in a site with similar climate conditions in southern Spain, and by Fioretto et al. (2003) for Cistus incanus (4.3 Mg DM ha ${ }^{-1}$ year $^{-1}$ ), in a site in southern Italy with similar annual rainfall (680 mm year ${ }^{-1}$ ) but warmer (mean annual temperature of $18.6^{\circ} \mathrm{C}$ ). For $\mathrm{CS}$, litter production $(3.3-3.8 \mathrm{Mg} \mathrm{DM}$ $\mathrm{ha}^{-1}$ year $\left.^{-1}\right)$ is similar to the mean reported by Cole and Rapp (1980), for a wide range of Mediterranean-type shrublands in France, California and Australia (3.8 Mg $\mathrm{DM} \mathrm{ha}{ }^{-1}$ year $\left.^{-1}\right)$. Litterfall of studied shrub species is similar to that recorded for Mediterranean tree species. For instance, CL litterfall is within the range reported by Escudero et al. (1985) for Q. rotundifolia (3.8-6.1 $\mathrm{Mg} \mathrm{DM} \mathrm{ha}{ }^{-1}$ year $^{-1}$ ), in a Spanish dehesa. Also, that of CS is within the range reported by Rapp et al. (1999) and Rodà et al. (1999), for Quercus ilex (3.5-3.9 Mg $\mathrm{DM}$ ha $^{-1}$ year $\left.^{-1}\right)$. The proportion of leaf litterfall observed for CL is similar to that reported for the same species $(85 \%)$ by Nuñez-Olivera et al. (1993), while that recorded for CS is close to that observed by Fioretto et al. (2003), for C. incanus (67\%).

The decrease of $\mathrm{N}$ and $\mathrm{P}$ concentration in leaf litter during peak leaf shedding, in the dry season, might be mostly due to reabsorption from senescing leaves to young growing material, prior to shedding, which is in agreement with the strong differences observed between concentrations in mature and senescing leaves (Simões et al. 2008). This also agrees with observations reported for tree species, in Mediterranean areas, with leaf fall peak in early-summer (e.g. Eucalyptus globulus, Madeira et al. 1995). It is noticeable that the decrease pattern of $\mathrm{P}$ concentration in CL leaf litter is not so clear, which may be in relation with the higher $\mathrm{P}$ concentration in mature leaves and leaf litter of CL. Ca concentration in CS leaves increases along leaf life span, due to the low mobility of this bio-element, leading to a maximum concentration at senescence, during the dry season (Simões et al. 2008), as observed for tree species in Mediterranean areas (Madeira et al. 1995; Gallardo et al. 1999; Santa Regina 2000).

Differences between studied species regarding annual potential return of bio-elements to the soil (except for P) tend to be lower than for litterfall mass, as nutrient concentrations in litterfall components were higher in CS than in CL. The mean annual $\mathrm{N}$ 
Table 9 Chemical characteristics of the mineral soil layers, at 0-5, 5-10, 10-20 and 20-30 cm depth, beneath C. salviifolius (BCS) and C. ladanifer (BCL) canopies, and in open areas (OP)

\begin{tabular}{|c|c|c|c|c|c|c|c|c|}
\hline \multirow[t]{2}{*}{ Loc } & \multicolumn{2}{|l|}{$\mathrm{pH}$} & \multicolumn{4}{|c|}{ Exchangeable base cations } & \multicolumn{2}{|c|}{ Extractables } \\
\hline & $\mathrm{H}_{2} \mathrm{O}$ & $\mathrm{KCl}$ & $\begin{array}{l}\mathrm{Ca}^{2+} \\
\mathrm{cmol}_{c} \mathrm{~kg}^{-1}\end{array}$ & $\mathrm{Mg}^{2+}$ & $\mathrm{Na}^{+}$ & $\mathrm{K}^{+}$ & $\begin{array}{l}\mathrm{P} \\
\mathrm{mg} \mathrm{kg}^{-1}\end{array}$ & $\mathrm{~K}$ \\
\hline \multicolumn{9}{|c|}{$0-5 \mathrm{~cm}$} \\
\hline BCS & $5.9 \pm 0.0^{\mathrm{a}}$ & $4.6 \pm 0.0^{\mathrm{a}}$ & $2.4 \pm 0.2^{\mathrm{a}}$ & $0.51 \pm 0.04^{\mathrm{a}}$ & $0.15 \pm 0.01$ & $0.22 \pm 0.02^{\mathrm{ab}}$ & $7.5 \pm 1.1$ & $78 \pm 7^{\mathrm{a}}$ \\
\hline BCL & $5.7 \pm 0.1^{\mathrm{b}}$ & $4.5 \pm 0.1^{\mathrm{ab}}$ & $2.2 \pm 0.2^{\mathrm{ab}}$ & $0.50 \pm 0.05^{\mathrm{a}}$ & $0.17 \pm 0.01$ & $0.25 \pm 0.02^{\mathrm{a}}$ & $9.5 \pm 1.2$ & $97 \pm 7^{\mathrm{a}}$ \\
\hline $\mathrm{OP}$ & $5.8 \pm 0.0^{\mathrm{ab}}$ & $4.3 \pm 0.1^{\mathrm{b}}$ & $1.7 \pm 0.1^{\mathrm{b}}$ & $0.38 \pm 0.03^{\mathrm{b}}$ & $0.15 \pm 0.01$ & $0.16 \pm 0.02^{\mathrm{b}}$ & $6.1 \pm 0.6$ & $42 \pm 8^{\mathrm{b}}$ \\
\hline \multicolumn{9}{|c|}{$5-10 \mathrm{~cm}$} \\
\hline BCS & $5.8 \pm 0.0$ & $4.3 \pm 0.1$ & $1.4 \pm 0.1$ & $0.36 \pm 0.03$ & $0.13 \pm 0.00^{\mathrm{a}}$ & $0.15 \pm 0.01^{\mathrm{a}}$ & $4.1 \pm 0.9$ & $50 \pm 3^{\mathrm{a}}$ \\
\hline BCL & $5.7 \pm 0.1$ & $4.2 \pm 0.1$ & $1.3 \pm 0.1$ & $0.39 \pm 0.03$ & $0.16 \pm 0.01^{\mathrm{b}}$ & $0.19 \pm 0.01^{\mathrm{b}}$ & $4.3 \pm 0.8$ & $65 \pm 5^{\mathrm{b}}$ \\
\hline OP & $5.7 \pm 0.1$ & $4.2 \pm 0.1$ & $1.5 \pm 0.1$ & $0.38 \pm 0.03$ & $0.15 \pm 0.01^{\mathrm{b}}$ & $0.13 \pm 0.01^{\mathrm{a}}$ & $4.0 \pm 0.5$ & $31 \pm 4^{\mathrm{c}}$ \\
\hline \multicolumn{9}{|c|}{$10-20 \mathrm{~cm}$} \\
\hline BCS & $5.7 \pm 0.1$ & $4.1 \pm 0.0$ & $1.2 \pm 0.1$ & $0.35 \pm 0.03$ & $0.13 \pm 0.00^{\mathrm{a}}$ & $0.13 \pm 0.01^{\mathrm{ab}}$ & $2.1 \pm 0.1$ & $43 \pm 2^{\mathrm{a}}$ \\
\hline $\mathrm{BCL}$ & $5.7 \pm 0.1$ & $4.1 \pm 0.1$ & $1.0 \pm 0.1$ & $0.38 \pm 0.04$ & $0.16 \pm 0.01^{\mathrm{b}}$ & $0.17 \pm 0.01^{\mathrm{b}}$ & $2.7 \pm 0.6$ & $59 \pm 5^{\mathrm{a}}$ \\
\hline OP & $5.6 \pm 0.1$ & $4.1 \pm 0.1$ & $1.1 \pm 0.1$ & $0.37 \pm 0.06$ & $0.15 \pm 0.01^{\mathrm{ab}}$ & $0.12 \pm 0.01^{\mathrm{a}}$ & $2.5 \pm 0.3$ & $29 \pm 4^{\mathrm{b}}$ \\
\hline \multicolumn{9}{|c|}{$20-30 \mathrm{~cm}$} \\
\hline BCS & $5.7 \pm 0.1$ & $4.0 \pm 0.0$ & $1.0 \pm 0.1$ & $0.32 \pm 0.04$ & $0.13 \pm 0.00^{\mathrm{a}}$ & $0.12 \pm 0.01$ & $1.4 \pm 0.1$ & $40 \pm 3$ \\
\hline BCL & $5.6 \pm 0.1$ & $3.9 \pm 0.0$ & $1.0 \pm 0.2$ & $0.36 \pm 0.08$ & $0.18 \pm 0.01^{\mathrm{b}}$ & $0.12 \pm 0.02$ & $1.5 \pm 0.3$ & $42 \pm 6$ \\
\hline OP & $5.6 \pm 0.1$ & $4.0 \pm 0.0$ & $1.0 \pm 0.1$ & $0.35 \pm 0.05$ & $0.15 \pm 0.01^{\mathrm{ab}}$ & $0.14 \pm 0.02$ & $1.6 \pm 0.3$ & $38 \pm 8$ \\
\hline
\end{tabular}

Values are mean \pm SE $(n=12)$. Means for the same nutrient and depth followed by different letters are significantly different $(P<0.05)$

and $\mathrm{K}$ amounts returned through litterfall of $\mathrm{CL}$ are higher than those reported by Núñez-Olivera et al. (1993) for the same species (13.9 $\mathrm{kg} \mathrm{N}$ and $9.9 \mathrm{~kg} \mathrm{~K}$ $\mathrm{ha}^{-1}$ year $^{-1}$ ). Both shrub species return higher amounts of bio-elements to the soil than trees in oak woodlands. In comparison with the annual $\mathrm{N}$ return observed by Escudero et al. (1985) for Q. rotundifolia (15.2 $\mathrm{kg} \mathrm{N} \mathrm{ha}^{-1}$ year $\left.^{-1}\right)$, the return of this bio-element was higher for both Cistus species. Return of $\mathrm{K}, \mathrm{Ca}$ and $\mathrm{Mg}$ was also higher for both shrub species (especially for $\mathrm{CL}$ ) than for $Q$. rotundifolia $(4.6 \mathrm{~kg}$ $\mathrm{K}, 13.7 \mathrm{~kg} \mathrm{Ca}$ and $2.3 \mathrm{~kg} \mathrm{Mg} \mathrm{ha}{ }^{-1}$ year $\left.^{-1}\right)$. It is noticeable the $\mathrm{P}$ return by CL (4.1 kg P ha ${ }^{-1}$ year $^{-1}$ ) which was about twice that by $\mathrm{CS}$, and 3.5 times higher than that reported by Escudero et al. (1985) for Q. rotundifolia $\left(1.2 \mathrm{~kg} \mathrm{P} \mathrm{ha}^{-1}\right.$ year $\left.{ }^{-1}\right)$. The high $\mathrm{P}$ return observed for $\mathrm{CL}$ is in agreement with that reported by Núñez-Olivera et al. (1993) for the same species (3.5 kg P ha ${ }^{-1}$ year $^{-1}$ ), and it is very interesting from an ecological point of view and also for the future management of extensive oak woodlands and Mediterranean rangelands. It suggests that CL may have stronger capacity than CS to improve P availability in soils, which may be beneficial for trees in the encroached early phase and to promote soil quality in degraded areas, since $\mathrm{P}$ can be a limiting bio-element in Mediterranean shrub communities, as observed by Martínez et al. (1998).

In interception calculation, stemflow (which is very difficult to measure) was not taken into account, and therefore part of the missing water in the balance could be stemflow. Even so, the study shrub species have a different role on rainfall interception (21 and 40\%, respectively for $\mathrm{CL}$ and CS). Rainfall interception by CL is similar to that observed by David et al. (2006) for $Q$. rotundifolia in the same study area $(22 \%)$ and is within the range reported by Llorens and Domingo (2007) for $Q$. ilex and Q. rotundifolia (18.8-36.4\%), while interception by $\mathrm{CS}$ is much higher than for trees and Mediterranean shrubs, e.g. Cistus laurifolius (28\%). Differences may be mostly a result of genetic-based differences in canopy structure. CL is characterised by sparse foliage clumps distributed vertically along higher and with larger gaps canopies, while CS leaves have a high degree of clustering and cover high percentage of canopy surface area (Simões et al. 2008). The CS canopy 
may act like an umbrella, conducting a high water proportion over its surface and channelizing it to the canopy edge. Also, the scabrid and rugose CS leaf surface might increase the interception efficiency.

Annual potential return of bio-elements by throughfall showed a wide interannual variation and was very low in comparison to those through litterfall, as reported for most forests in Mediterranean ecosystems (Bellot and Escarré 1991). The observed strong interannual variation may be in relation with the marked differences regarding precipitation amounts during the study period. Although nutrient concentrations are higher in CS foliage (Simões et al. 2008), amounts of nutrients returned by throughfall were higher for CL, which may be mostly explained by the higher dripping under CL. Such a difference may also be influenced by the higher leaf area index of CL than of CS (Simões et al. 2008). The depletion of $\mathrm{N}$ from rainfall suggests net absorption by shrub canopies, as previously observed in other shrub species (Moro et al. 1996), Q. rotundifolia (Avila et al. 2002) and $Q$. pyrenaica (Moreno et al. 2001) in Mediterranean ecosystems with low $\mathrm{N}$ availability. This suggests that leaves of studied Cistus species may act as a net sink for $\mathrm{N}$, indicating that atmospherically deposited $\mathrm{N}$ is being retained within the ecosystem and a build-up of $\mathrm{N}$ pools in the soil and vegetation is likely, as suggested by Rodà et al. (2002) for Mediterranean forests in Spain. In spite of a higher $\mathrm{N}$ concentration in $\mathrm{CS}$ than in $\mathrm{CL}$ leaves (Simões et al. 2008), the better ability to capture $\mathrm{N}$ from rainfall exhibited by the former may be in relation to differences in canopy exchange strategies between species, which should deserve special research attention. The observed $\mathrm{S}_{-} \mathrm{SO}_{4}{ }^{2-}$ absorption suggests a certain independence from the soil as a nutrient source, favouring even nutrient availability in the ecosystem, as reported by Quilchano et al. (2002) for Mediterranean forest ecosystems. The acidifying throughfall trend shown by CL may be in relation with the low base cation concentration in its leaves (Simões et al. 2008) and possible acid organic compounds.

Accumulation and turnover of organic matter on the soil

The higher necromass under CL (3.2 $\mathrm{Mg} \mathrm{DM} \mathrm{ha}^{-1}$ ) relative to CS (1.9 $\left.\mathrm{Mg} \mathrm{DM} \mathrm{ha}^{-1}\right)$ is in agreement with a higher litter fall amount and a lower leaf litter decomposability for CL, which may be mainly caused by a higher $\mathrm{C}$-to-N ratio (113 versus 70$)$. Those values are within the range reported by Escudero et al. (1985) for litter amount beneath $Q$. rotundifolia (1.74.6 $\mathrm{Mg} \mathrm{DM} \mathrm{ha}{ }^{-1}$ ). Also, amounts of necromass under shrub canopies fall within the range observed by Nunes (2004) for Q. rotundifolia (1.3-3.0 Mg DM $\mathrm{ha}^{-1}$ ), in the neighbourhood of the study area. Similar necromass observed for CL and Q. rotundifolia is in agreement with litterfall amounts of the same magnitude, and also with the similar decomposition rate exhibited by the leaf litter of CL $\left(-0.44\right.$ year $\left.^{-1}\right)$ as compared to that for $Q$. rotundifolia $\left(-0.48\right.$ year $\left.^{-1}\right)$ (Sá et al. 2005). The necromass beneath CS is close to the lower limit of range reported for $Q$. rotundifolia, which is in agreement with its lower litterfall and higher decomposition rate $\left(-0.87\right.$ year $\left.^{-1}\right)$ as compared to trees.

The small amount of necromass accumulated beneath CS canopies can be mostly explained by the fast leaf litter decomposition, given that the decomposition rate $\left(0.87\right.$ year $\left.^{-1}\right)$ is close to the turnover of litterfall, 0.71 year $^{-1}$, obtained with the Olson's (1963) approach, since the annual litterfall was 3.6 $\mathrm{Mg} \mathrm{DM} \mathrm{ha}{ }^{-1}$ year $^{-1}$ and the amount of litter beneath shrub canopies before litterfall peak was $1.5 \mathrm{Mg}$ DM $\mathrm{ha}^{-1}$. For CL, however, the small litter amount on soil surface is unexpected, taking into account the decomposition rate $\left(0.44\right.$ year $\left.^{-1}\right)$, which is much lower than the calculated turnover rate, 0.73 year $^{-1}$, since annual litterfall was 4.5 Mg DM ha ${ }^{-1}$ year $^{-1}$ and necromass on soil surface before litterfall peak was 1.7 Mg DM ha ${ }^{-1}$. This difference between the expected and the actual litter accumulation suggests a considerable increase in the organic residues turnover rate, which may be related to the activity (consumption and transference of new litterfall) of herbivorous animals (and possibly of mesofauna), as reported by Escudero et al. (1985) for dehesa ecosystems.

Besides differences in necromass, nutrient amounts in litter beneath shrub canopies also depend on nutrient release dynamics from decomposing residues. For instance, the similar amounts of $\mathrm{P}$ in necromass beneath CL and CS may be in relation with the faster $\mathrm{P}$ release from decomposing leaf litter from CL than from CS (see Fig. 3).

Soil properties

The study shrubs may have a positive role on SOC (10.3-11.4 $\mathrm{g} \mathrm{kg}^{-1}$ in the $0-5 \mathrm{~cm}$ top soil layer), as 
reported for other Mediterranean shrubs (Moro et al. 1996; Monokrousos et al. 2004) and shrubs in a subtropical savanna (Hibbard et al. 2001), following the pattern observed for trees in oak woodlands of Mediterranean areas (Dahlgren et al. 1997; Nunes 2004; Moreno and Obrador 2007). However, relative to barren areas $\left(8.1 \mathrm{~g} \mathrm{~kg}^{-1}\right)$, the increment of SOC was low, which is in line with average values reported by Moreno and Obrador (2007) for dehesas encroached after 10-15 years. As the accumulation of organic $\mathrm{C}$ is a slow process (Madeira and Ribeiro 1995), it is expected that the difference beneath shrubs and barren areas will increase with time. The increment of SOC beneath shrubs might be ascribed both to the deposition of organic residues on soil surface by litterfall and to root litter. As the increment of organic $\mathrm{C}$ beneath shrub canopies mostly occurs in the $0-5 \mathrm{~cm}$ top soil layer and is mostly related with the POM fraction (59-64\%) (see Table 8), the amounts of organic residues annually deposited on the soil surface through litterfall may have a major role on such increment. Also, the similar proportion of the POM fraction in soil beneath shrubs (62-63\%) and in the barren areas (63\%) suggests that either herbaceous species (protected from browsing) or shrub roots are actively influencing the input of SOC. Nevertheless, detailed studies on root system of studied shrubs are needed to assess its effect on the pattern of SOC distribution.

The increment of soil $\mathrm{N}$ beneath shrubs relative to barren areas (4-7\%) was lower than that observed for the SOC $(27-41 \%)$. This led to a higher $\mathrm{C}$-to-N ratio beneath shrubs (13.4-15.2) than in the open areas (11.3), which may be in relation with a higher C-to-N ratio of shrub residues (70 and 113), as compared to that of herbaceous plants (58) (Cortez et al. 2007). This pattern does not agree with data reported by Moreno and Obrador (2007) for dehesas in Spain, in which a significant increase of organic $\mathrm{N}$ was observed in soil of encroached areas (where leguminous shrub species-Genista hirsuta and Retama sphaerocarpa-were dominant), while that of SOC was slight and not significant, leading to a lower soil $\mathrm{C}$-to-N ratio. These differences point out that the amount of $\mathrm{N}$ in the soils may depend on shrub species and also on OM quality, as reported by Gallardo and Merino (1998) for soils of a Mediterranean shrubland in Spain. In spite of a higher annual $\mathrm{N}$ return in CS (22.6-23.2 $\mathrm{kg} \mathrm{N} \mathrm{ha}^{-1}$ year $\left.^{-1}\right)$ than in CL (16.7-
$17.7 \mathrm{~kg} \mathrm{~N} \mathrm{ha}{ }^{-1}$ year $^{-1}$ ), $\mathrm{N}$ concentration in soil beneath them was similar, which may be related with lower $\mathrm{N}$ mineralization rate in decomposing residues and soil beneath $\mathrm{CL}$, given the higher $\mathrm{C}$-to- $\mathrm{N}$ ratio.

The decrease of soil bulk density in the $0-5 \mathrm{~cm}$ soil layer beneath shrub canopies, in comparison to the barren spaces (see Table 7), follows the trend observed for oak woodlands of Mediterranean areas (Dahlgren et al. 1997; Cubera and Moreno 2007). Differences in soil bulk density indicate that total soil porosity beneath shrubs is higher $(55 \%)$ than in open areas $(51 \%)$. The increasing soil porosity under shrub canopies may be a result of a stronger biological activity due to higher amounts of decomposing residues (litterfall and root litter) and of dead root channels (biopores), as considered by Brady and Weil (1999). Soil surface protection by organic layers may also enhance soil porosity, and roots may improve soil structure, increasing infiltration rates (Schlesinger and Pilmanis 1998; Archer et al. 2002), which will contribute to reduce soil erosion (Andreu et al. 1998). The negligible difference of water holding capacity (at several matric potential values) exhibited by soils under shrub cover and in the open area is in agreement with the small differences regarding SOM and porosity in soils of the studied areas. This suggests that significant changes of soil physical characteristics can only be achieved after long periods of shrub development.

Our results confirmed the general pattern of high spatial heterogeneity of soil nutrients and fertility, associated with shrub vegetation, reported for several shrublands in semiarid and arid regions (Miles 1985; Schlesinger et al. 1996; Whitford et al. 1997; Schlesinger and Pilmanis 1998; Van Breemen and Finzi 1998; Gimeno-García et al. 2001; Castells and Peñuelas 2003), and in humid temperate climates (Spears et al. 2001). Higher concentrations of exchangeable $\mathrm{Ca}^{2+}, \mathrm{Mg}^{2+}$ and $\mathrm{K}^{+}$, and extractable $\mathrm{P}$ and $\mathrm{K}$, were measured in soil under the shrubs than in the intershrub spaces. This pattern followed that observed for holm oak trees in the study area (Nunes et al. 2005), albeit to a lesser extent, which may be in relation with the shorter period of shrubs development as compared to that of trees. As for SOC, the increment of exchangeable $\mathrm{Ca}^{2+}$ and $\mathrm{Mg}^{2+}$, and extractable $\mathrm{P}$ was only observed in the $0-5 \mathrm{~cm}$ top soil layer, whereas $\mathrm{K}$ concentrations were noticed beyond the $0-5 \mathrm{~cm}$ top soil layer, which may be in 
relation with the higher $\mathrm{K}$ mobility in the top soil, as reported by Gómez-Rey et al. (2008). Given the similar annual potential return of bio-elements through litterfall and throughfall of $\mathrm{CL}$ and $\mathrm{CS}$, nutrient concentrations in soil beneath these species were of the same magnitude. However, we may emphasize the high $\mathrm{P}$ return through litterfall and the higher extractable $\mathrm{P}$ concentration beneath CL, which might be of great importance for many Mediterranean ecosystems, where $\mathrm{P}$ is considered as one of the major limiting factors (Vallejo et al. 2006). Both shrub species may positively affect the system functioning owing to the general low nutrient status of soils of the study area (Nunes et al. 2005).

\section{Conclusions}

Studied shrub species, through uptake of soil nutrients and the subsequent deposition of litter under the canopy and leaching from green leaves and litter, improved soil quality by enhancement of organic C and nutrient status, especially in the $0-5 \mathrm{~cm}$ top soil layer. Since shrubs of CL revealed a $\mathrm{C}$ and $\mathrm{N}$ more conserving behaviour and, in contrast, a higher $\mathrm{P}$ turnover than $\mathrm{CS}, \mathrm{P}$ cycle is expected to be faster in sites dominated by CL, while $\mathrm{C}$ and $\mathrm{N}$ cycles are likely to be slower. Although the distribution of soil properties was markedly patchy, with higher nutrient contents beneath shrubs than in the barren spaces, longer encroachment periods may be needed to significantly increase soil quality, particularly organic C content. Soil patches observed beneath shrub canopies may be important local nutrient sinks that influence community structure and ecosystem function, suggesting that the shrub component may also play an important role on the spatial and temporal heterogeneity of oak woodland soils. Therefore, shrub development may promote the invasion of more demanding species, since local areas of high fertility are likely to be favoured sites for vegetation regeneration. Then, both studied Cistus species may be associated not only with stages of retrogressive succession, but also with oak regeneration and stages of secondary progressive succession.

Acknowledgements This study was developed within the activities of the Instituto de Ciências Agrárias Mediterrânicas and the Centro de Pedologia of the Portuguese Fundação para a Ciência e Tecnologia. Authors thank Prof. Manuela Morais of the Centro de Ecologia Aplicada and the staff of the Soil Laboratory of the Instituto Superior de Agronomia for chemical analyses. Dr. Jorge Nunes and the technicians of the Botany Laboratory of Universidade de Évora are also acknowledged for field and laboratory assistance.

\section{References}

Andreu V, Rubio JL, Cerni R (1998) Effects of Mediterranean shrub cover on water erosion (Valencia, Spain). J Soil Water Conserv 53:112-120

Archer N, Hess T, Quinton J (2002) The water balance of two semi-arid shrubs on abandoned land in South-Eastern Spain after cold season rainfall. Hydrol Earth Syst Sci 6:913-926

Avila A, Rodrigo A, Rodà F (2002) Nitrogen circulation in a Mediterranean holm oak forest, La Castanya, Montseny, Northeastern Spain. Hydrol Earth Syst Sci 6:551-557

Bastida F, Talavera S (2002) Temporal and spatial patterns of seed dispersal in two Cistus species (Cistaceae). Ann Bot (Lond) 89:427-434 doi:10.1093/aob/mcf065

Bellot J, Escarré A (1991) Chemical characteristics and temporal variations of nutrients in throughfall and stemflow of three species in Mediterranean holm oak forest. For Ecol Manag 41:125-135

Blondel J, Aronson J (1999) Biology and Wildlife of the Mediterranean Region. Oxford Univ Press, New York

Brady NC, Weil RR (1999) The Nature and Properties of Soils, 12th edn. Prentice Hall, Upper saddle River, New Jersey

Bruckert S (1979) Analyse des complexes organominéreaux des sols. In: Duchaufour P, Souchier B (eds) Pédologie 2. Constituants et Propriétées du Sol. Masson \& Cie, Paris, pp 185-209

Carvalhosa AB, Carvalho AMG, Alves CAM (1969) Notícia explicativa da folha 40-A-Évora da Carta Geológica de Portugal na escala de 1/50 000. Serviços Geológicos de Portugal, Lisboa

Castells E, Peñuelas J (2003) Is there a feedback between N availability in siliceous and calcareous soils and Cistus albidus leaf chemical composition? Oecologia 136:183192 doi:10.1007/s00442-003-1258-8

Castroviejo S, Aedo C, Cirujano S, Laínz M, Montserrat P, Morales R, Garmendia FM, Navarro C, Paiva J, Soriano C (1993) Flora Iberica. Plantas vasculares de la Península Ibérica e Islas Baleares, vol. vol 3. Real Jardín Botánico, CSIC, Madrid

Cole DW, Rapp M (1980) Elemental cycling in forest ecosystems. In: Reichle DE (ed) Dynamic properties of forest ecosystems. IBP 23, Cambridge Univ Press, Cambridge, pp 341-409

Correia OA, Martins AC, Catarino FM (1992) Comparative phenology and seasonal foliar nitrogen variation in mediterranean species of Portugal. Ecol Medit 18:7-18

Cortez J, Garnier E, Pérez-Harguindeguy N, Debussche M, Gillon D (2007) Plant traits, litter quality and decomposition in a Mediterranean old-field succession. Plant Soil 296:19-34 doi:10.1007/s11104-007-9285-6 
Cubera E, Moreno G (2007) Effect of single Quercus ilex trees upon spatial and seasonal changes in soil water content in dehesas of central western Spain. Ann Sci 64:355-364 doi:10.1051/forest:2007012

Dahlgren RA, Singer MJ, Huang X (1997) Oak trees and grazing impacts on soil properties and nutrients in a California oak woodland. Biogeochemistry 39:45-64 doi:10.1023/A:1005812621312

David TS, Gash JHC, Valente F, Pereira JS, Ferreira MI, David JS (2006) Rainfall interception by an isolated evergreen oak tree in a Mediterranean savannah. Hydrol Process 20:2713-2726 doi:10.1002/hyp.6062

DGF (2007) Inventário Florestal Nacional (2005-2006). Direcção-Geral das Florestas, Lisboa

Dorich RA, Nelson DW (1983) Direct colorimetric measurement of ammonium in potassium chloride extracts of soils. Soil Sci Soc Am J 47:833-836

Eichhorn MP, Paris P, Herzog F, Incoll LD, Liagre F, Mantzanas K, Mayus M, Moreno G, Papanastasis VP, Pilbeam DJ, Pisanelli A, Dupraz C (2006) Silvoarable systems in Europe-past, present and future prospects. Agrofor Syst 67:29-50 doi:10.1007/s10457-005-1111-7

Escudero A, García B, Gómez JM, Luís E (1985) The nutrient cycling in Quercus rotundifolia and Quercus pyrenaica ecosystems (dehesas) of Spain. Acta Oecol 6:73-86

Fioretto A, Papa S, Fuggi A (2003) Litter-fall and litter decomposition in a low Mediterranean shrubland. Biol Fertil Soils 39:37-44 doi:10.1007/s00374-003-0675-5

Fulbright TE (1996) Viewpoint: a theoretical basis for planning woody plant control to maintain species diversity. J Range Manage 49:554-559 doi:10.2307/4002299

Gallardo A, Merino J (1998) Soil nitrogen dynamics in response to carbon increase in a Mediterranean shrubland of SW Spain. Soil Biol Biochem 30:1349-1358 doi:10.1016/S0038-0717(97)00265-4

Gallardo JF, Martín A, Moreno G (1999) Nutrient efficiency and resorption in Quercus pyrenaica oak coppices under different rainfall regimes of the Sierra de Gata mountains (central western Spain). Ann Sci 56:321-331 doi:10.1051/ forest: 19990406

Gimeno-García E, Andreu V, Rubio JL (2001) Influence of Mediterranean shrub species on soil chemical properties in typical Mediterranean environment. Commun Soil Sci Plant Anal 32:1885-1898 doi:10.1081/CSS-120000256

Gómez-Rey MX, Vasconcelos E, Madeira M (2008) Effects of eucalypt residue management on nutrient leaching and soil properties. Eur J For Res. doi:10.1007/s10342-008-0217-7

Gordon AM, Chourmouzis C, Gordon AG (2000) Nutrient inputs in litterfall and rainwater fluxes in 27-year old red, black and white spruce plantations in Central Ontario, Canada. For Ecol Manag 138:65-78

Hibbard KA, Archer S, Schimel DS, Valentine DW (2001) Biogeochemical changes accompanying woody plant encroachment in a subtropical Savanna. Ecology 82:1999-2011

Houba VJG, Novozamsky I, Tenminghoff E (1994) Soil Analysis Procedures. Department of Soil Science and Plant Nutrition, Wageningen Agricultural University, The Netherlands

Joffre R, Rambal S, Ratte PJ (1999) The dehesa system of southern Spain and Portugal as a natural ecosystem mimic. Agrofor Syst 45:57-79 doi:10.1023/A:1006259402496
Llorens P, Domingo F (2007) Rainfall partitioning by vegetation under Mediterranean conditions. A review of studies in Europe. J Hydrol (Amst) 335:37-54 doi:10.1016/j. jhydrol.2006.10.032

Madeira M, Ribeiro C (1995) Influence of leaf litter type on the chemical evolution of a soil parent material (sandstone). Biogeochemistry 29:43-58 doi:10.1007/BF00002593

Madeira M, Araújo MC, Pereira JS (1995) Effects of water and nutrient supply on amount and on nutrient concentration of litterfall and forest floor litter in Eucalyptus globulus plantations. Plant Soil 168-169:287-295 doi:10.1007/ BF00029340

Martín Bolaños M, Guinea López E (1949) Jarales y Jaras (Cistografia Hispanica). Ministerio de Agricultura, Madrid

Martínez F, Merino O, Martín A, García Martín D, Merino J (1998) Belowground structure and production in a Mediterranean sand dune shrub community. Plant Soil 201:209-216 doi:10.1023/A:1004389329411

Miles J (1985) The pedogenic effects of different species and vegetation types and the implications of succession. J Soil Sci 36:571-584 doi:10.1111/j.1365-2389.1985. tb00359.x

Miranda P, Coelho FES, Tomé AR, Valente MA (2002) 20th century Portuguese climate and climate scenarios. In: Santos FD, Forbes K, Moita R (eds) Climate Change in Portugal: Scenarios, Impacts and Adaptation Measures, SIAM project. Gradiva, Lisboa, pp 25-83

Monokrousos N, Papatheodorus EM, Diamantopoulos JD, Stamou GP (2004) Temporal and spatial variability of soil chemical and biological variables in a Mediterranean shrubland. For Ecol Manage 202:83-91

Moreno G, Obrador JJ (2007) Effects of trees and understory management on soil fertility and nutrient status of holm oaks in Spanish dehesas. Nutr Cycl Agroecosyst 78:253264 doi:10.1007/s10705-007-9089-3

Moreno G, Gallardo JF, Bussotti F (2001) Canopy modification of atmospheric deposition in oligotrophic Quercus pyrenaica forests of an unpolluted region (central-western Spain). For Ecol Manag 149:47-60

Moro MJ, Domingo F, Escarré A (1996) Organic matter and nitrogen cycles in a pine afforested catchment with a shrub layer of Adenocarpus decorticans and Cistus laurifolius in south-eastern Spain. Ann Bot (Lond) 78:675-685 doi:10.1006/anbo.1996.0177

Nunes J (2004) Interacção solo-árvore isolada em montados de azinho (Quercus rotundifolia Lam.): processos fundamentais. Ph. D. Thesis. Universidade de Évora, Évora, Portugal

Nunes J, Madeira M, Gazarini L (2005) Some ecological impacts of Quercus rotundifolia trees on the understory environment in the "montado" agrosilvopastoral system, Southern Portugal. In: Mosquera-Losada MR, Riguero Rodriguez A, McAdam J (eds) Silvopastoralism and Sustainable Land Management. CAB International, Oxfordshire, pp 275-277

Núñez-Olivera E, Martínez-Abaigar J, Escudero-García JC (1993) Litterfall and nutrient flux in Cistus ladanifer L. shrubland in S.W. Spain. Acta Oecol 14:361-369

Olson JS (1963) Energy storage and the balance of producers and decomposers in ecological systems. Ecology 44:322331 doi: $10.2307 / 1932179$ 
Pérez-García F (1997) Germination of Cistus ladanifer seeds in relation to parent material. Plant Ecol 133:57-62 doi:10.1023/A:1009776910683

Plieninger T, Pulido FJ, Konold W (2003) Effects of land-use history on size structure of holm oak stands in Spanish dehesas: implications for conservation and restoration. Environ Conserv 30:61-70 doi:10.1017/S03768929030 00055

Plieninger T, Pulido FJ, Schaich H (2004) Effects of land-use and landscape structure on holm oak recruitment and regeneration at farm level in Quercus ilex L. dehesas. J Arid Environ 57:345-364 doi:10.1016/S0140-1963(03)00103-4

Pulido F, Díaz M (2005) Regeneration of a Mediterranean oak: a whole cycle approach. Ecoscience 12:92-102 doi:10.2980/i1195-6860-12-1-92.1

Pulido FJ, Díaz M, de Trucios SJH (2001) Size structure and regeneration of Spanish holm oak Quercus ilex forests and dehesas: effects of agroforestry use on their long-term sustainability. For Ecol Manag 146:1-13

Quilchano C, Haneklaus S, Gallardo JF, Schnug E, Moreno G (2002) Sulphur balance in a broadleaf, non-polluted, forest ecosystem (central-western Spain). For Ecol Manag 161:205-214

Ramos Solano B, Pereyra de la Iglesia MT, Probanza A, Lucas García JA, Megías M, Gutierrez Mañero FJ (2006) Screening for PGPR to improve growth of Cistus ladanifer seedlings for reforestation of degraded mediterranean ecosystems. Plant Soil 287:59-68 doi:10.1007/s11104-006-9055-x

Rapp M, Santa Regina I, Rico M, Gallego HA (1999) Biomass, nutrient content, litterfall and nutrient return to the soil in Mediterranean oak forests. For Ecol Manag 119:39-49

Reis RMM, Gonçalves MZ (1987) Clima de Portugal, Fascículo XXXIV. Caracterização climática da região agrícola do Alentejo. Instituto Nacional de Meteorologia e Geofísica, Lisboa

Riehm H (1958) Die ammoniumlaktatessignäure. Methode zur bestimmung der leichtloslichen phosphorsäure in karbonataligen böden. Agrochimica 3:49-65

Rivas-Martínez S, Penas A, Díaz TE (2004) Biogeographic and bioclimatic maps of Europe. Serviços Cartográficos da Universidad de Léon, Léon

Rodà F, Mayor X, Sabaté S, Diego V (1999) Water and nutrient limitations to primary production. In: Rodà $\mathrm{F}$, Retana $\mathrm{J}$, Gracia CA, Bellot J (eds) Ecology of Mediterranean Evergreen Oak Forests. Ecological Studies 137. SpringerVerlag, Berlin, pp 183-194
Rodà F, Avila A, Rodrigo A (2002) Nitrogen deposition in Mediterranean forests. Environ Pollut 118:205-213 doi:10.1016/S0269-7491(01)00313-X

Sá C, Madeira M, Gazarini L (2005) Produção e decomposição de folhas da folhada de Quercus suber L. e Q. rotundifolia Lam. Rev Cienc Agrarias 28:257-272

Santa Regina I (2000) Organic matter distribution and nutrient fluxes within a sweet chestnut (Castanea sativa Mill.) stand of the Sierra de Gata, Spain. Ann Sci 57:691-700 doi:10.1051/forest:2000150

Schlesinger WH, Pilmanis AM (1998) Plant-soil interactions in deserts. Biogeochemistry 42:169-187 doi:10.1023/ A: 1005939924434

Schlesinger WH, Raikes JA, Hartley AE, Cross AE (1996) On the spatial pattern of soil nutrients in desert ecosystems. Ecology 72:364-374 doi:10.2307/2265615

Simões MP, Madeira M, Gazarini L (2008) The role of phenology, growth and nutrient retention during leaf fall in the competitive potential of two species of Mediterranean shrubs in the context of global climate changes. Flora 203:578-589

Spears JDH, Lajtha K, Caldwell BA, Pennington SB, Vanderbilt K (2001) Species effects of Ceanothus velutinus versus Pseudotsuga menziesii, Douglas-fir, on soil phosphorus and nitrogen properties in the Oregon cascades. For Ecol Manag 149:205-216

Vallejo R, Aronson J, Pausas J, Cortina J (2006) Restoration of Mediterranean Woodlands. In: Andel JV, Aronson J (eds) Restoration Ecology. The New Frontier. Blackwell Pub, Oxford, pp 193-207

Van Breemen N, Finzi AC (1998) Plant-soil interactions: ecological aspects and evolutionary implications. Biogeochemistry 42:1-19 doi:10.1023/A:1005962124317

Whitford WG, Anderson J, Rice PM (1997) Stemflow contribution to the 'fertile island' effect in creosotebush, Larrea tridentata. J Arid Environ 35:451-457 doi:10.1006/jare.1996.0164

WRB (2006) World Reference Base for Soil Resources, 2nd edn. World Soil Resources Reports $N^{\circ}$. 103. FAO, Rome

Zunzunegui M, Díaz Barradas MC, Ain-Lhout F, Clavijo A, García Novo F (2005) To live or to survive in Doñana dunes: adaptive responses of woody species under a Mediterranean climate. Plant Soil 273:77-89 doi:10. 1007/s11104-004-6806-4 